OPEN ACCESS

Edited by: Xingxing Peng,

Sun Yat-sen University, China

Reviewed by:

Fabrice Martin-Laurent

Institut National de la Recherche

Agronomique (INRA), France

Alessandro D'Annibale,

Tuscia University, Italy

*Correspondence:

Shaohua Chen

shchen@scau.edu.cn

Specialty section:

This article was submitted to

Microbiotechnology,

a section of the journal

Frontiers in Microbiology

Received: 27 March 2021

Accepted: 16 July 2021

Published: 12 August 2021

Citation:

Li J, Zhang W, Lin Z, Huang Y, Bhatt $P$ and Chen $S$ (2021) Emerging Strategies for the Bioremediation of the Phenylurea Herbicide Diuron.

Front. Microbiol. 12:686509.

doi: 10.3389/fmicb.2021.686509

\section{Emerging Strategies for the Bioremediation of the Phenylurea Herbicide Diuron}

\author{
Jiayi Li ${ }^{1,2}$, Wenping Zhang ${ }^{1,2}$, Ziqiu Lin ${ }^{1,2}$, Yaohua Huang ${ }^{1,2}$, Pankaj Bhatt ${ }^{1,2}$ and \\ Shaohua Chen ${ }^{1,2 *}$
} 'State Key Laboratory for Conservation and Utilization of Subtropical Agro-Bioresources, Guangdong Province Key
Laboratory of Microbial Signals and Disease Control, Integrative Microbiology Research Centre, South China Agricultural
University, Guangzhou, China, ${ }^{2}$ Guangdong Laboratory for Lingnan Modern Agriculture, Guangzhou, China

Diuron (DUR) is a phenylurea herbicide widely used for the effective control of most annual and perennial weeds in farming areas. The extensive use of DUR has led to its widespread presence in soil, sediment, and aquatic environments, which poses a threat to non-target crops, animals, humans, and ecosystems. Therefore, the removal of DUR from contaminated environments has been a hot topic for researchers in recent decades. Bioremediation seldom leaves harmful intermediate metabolites and is emerging as the most effective and eco-friendly strategy for removing DUR from the environment. Microorganisms, such as bacteria, fungi, and actinomycetes, can use DUR as their sole source of carbon. Some of them have been isolated, including organisms from the bacterial genera Arthrobacter, Bacillus, Vagococcus, Burkholderia, Micrococcus, Stenotrophomonas, and Pseudomonas and fungal genera Aspergillus, Pycnoporus, Pluteus, Trametes, Neurospora, Cunninghamella, and Mortierella. A number of studies have investigated the toxicity and fate of DUR, its degradation pathways and metabolites, and DUR-degrading hydrolases and related genes. However, few reviews have focused on the microbial degradation and biochemical mechanisms of DUR. The common microbial degradation pathway for DUR is via transformation to 3,4-dichloroaniline, which is then metabolized through two different metabolic pathways: dehalogenation and hydroxylation, the products of which are further degraded via cooperative metabolism. Microbial degradation hydrolases, including PuhA, PuhB, LibA, HylA, Phh, Mhh, and LahB, provide new knowledge about the underlying pathways governing DUR metabolism. The present review summarizes the state-of-the-art knowledge regarding (1) the environmental occurrence and toxicity of DUR, (2) newly isolated and identified DUR-degrading microbes and their enzymes/genes, and (3) the bioremediation of DUR in soil and water environments. This review further updates the recent knowledge on bioremediation strategies with a focus on the metabolic pathways and molecular mechanisms involved in the bioremediation of DUR.

Keywords: diuron, ecotoxicity, bioremediation, metabolic pathways, molecular mechanisms, biodegradation 


\section{INTRODUCTION}

Diuron [1-(3,4 dichlorophenyl)-3,3 dimethyl urea] (DUR) is an active ingredient in the formulation of several plant protection products and biocides. It is widely used for the pre- or postemergence control of various types of broadleaf and grassy weeds in diverse crops such as cotton, fruit, and cereals, as well as for algal control in fish production ponds, with application doses ranging from 0.45 to $3 \mathrm{~kg}$ a.i. ha ${ }^{-1}$ (Castillo et al., 2006; Stork et al., 2008; Lu et al., 2019; Tandon and Pant, 2019). It has also been used in antifouling paints for boating activities and noncrop applications such as roads, garden paths, and railway lines (Schrader et al., 2004; Hussain et al., 2015).

Continuous use of DUR has resulted in the contamination of the environment and raised public concern about its impact on human health. In mammals, including humans, DUR $(0.05-0.5 \mu \mathrm{g} / \mathrm{L})$ is suspected of having carcinogenic, mutagenic, and neurotoxic effects, causing genotoxicity, cytotoxicity, embryotoxicity, and immunotoxicity, as well as a disruption of endocrine, respiratory, and cardiovascular processes (da Rocha et al., 2013; Behrens et al., 2016; Manonmani et al., 2020). This compound $(200 \mathrm{ng} / \mathrm{L})$ is also harmful to fish, plants, aquatic invertebrates, freshwater algae, and microbial species (Pesce et al., 2010; Pereira et al., 2015; Wilkinson et al., 2017; Pei et al., 2020). In addition, some metabolites of DUR, such as 3,4-dichloroaniline (3,4-DCA) and 3-(3,4-dichlorophenyl)-1methylurea (DCPMU), showed more ecotoxicological effects than their parent compound (Stork et al., 2008; Hussain et al., 2015). Therefore, remediation strategies in situ should decrease their persistence, avoid their transfer, and have a positive impact on terrestrial and living organisms.

Various technologies have emerged to remove DUR from the environment and reduce its harmful effects, including advanced physical adsorption, photocatalytic degradation, chemical degradation, and biological treatments (da Silva Teófilo et al., 2020; de Souza and Dos Santos, 2020; Park and Jhung, 2020; Silambarasan et al., 2020). However, previous studies have reported that the by-products of the abiotic transformation of this compound are more hazardous than the parent compound itself (Liu et al., 2018; Manonmani et al., 2020). Moreover, DUR can be released back into the soil after the formation of bound residues via physical adsorption (Dias Guimaraes et al., 2018). Microbial degradation has advantages over other degradation methods because it is cost-effective and environmentally friendly, making it well suited for the bioremediation of many organic pollutants from different environments (Peng et al., 2012; Birolli et al., 2019; Bhatt et al., 2021b). Numerous bacteria, fungi, and actinomycetes have been isolated and identified as capable of degrading DUR (Ellegaard-Jensen et al., 2014; Hussain et al., 2015; Grandclement et al., 2017; Villaverde et al., 2017, 2018). However, few reviews have focused on the microbial degradation and biochemical mechanisms of DUR (Giacomazzi and Cochet, 2004; Hussain et al., 2015).

The present review summarizes up-to-date information on DUR in its environmental occurrence and toxicity, along with the newly isolated and characterized DUR-degrading microorganisms and their application for the bioremediation of
DUR in soil and water environments. This review emphasizes the metabolic pathways and degradation mechanisms that dissipate DUR, with additional focus on the advances of hydrolases and related genes, to provide novel facts underlying the metabolic pathways governing these processes. Finally, environmental factors affecting the practical application of microorganisms for the bioremediation of DUR are explained, providing a better understanding of how microorganisms promote the natural dissipation of DUR, thereby limiting its dispersion in the environment.

\section{ENVIRONMENTAL OCCURRENCE AND TOXICITY}

\section{Environmental Occurrence}

Due to their high persistence and extensive use, DUR residues are frequently found in water, soil, and sediments (Field et al., 2003; Giacomazzi and Cochet, 2004; Tandon and Pant, 2019). The highest concentration of DUR in sediment samples in the Brazilian Amazon region was $55.2 \mu \mathrm{g} / \mathrm{kg}$ (Viana et al., 2019). In Costa Rica river basins, the highest DUR concentration in water and sediment samples were $22.8 \mu \mathrm{g} / \mathrm{L}$ and $11.75 \mu \mathrm{g} / \mathrm{kg}$, respectively (Carazo-Rojas et al., 2018). Loos et al. (2009) reported that approximately $70 \%$ of samples from European streams contained the maximum concentration of DUR at $864 \mathrm{ng} / \mathrm{L}$. In Europe, the maximum allowable concentration and annual average concentration of DUR in surface water are set to 1.8 and $0.2 \mu \mathrm{g} / \mathrm{L}$, respectively, with DUR already being included in the 2019 European Commission Priority Substance list (Mori et al., 2018). The European Union guideline value for DUR in drinking water is $0.1 \mu \mathrm{g} / \mathrm{L}$ (DWI, 2013). In addition to the parent compound, DUR degradation metabolites have also been detected in soil and aquatic environments around the world (Hussain et al., 2015). Moreover, its relatively high solubility and long aqueous photolysis half-life $\left(\mathrm{DT}_{50}\right)$ make it available in water fractions such as rivers, streams, lakes, and seawater (Felício et al., 2018). The European Food Safety Authority reported that the $\mathrm{DT}_{50}$ of DUR in the soil ranges from 14 to 372 days under aerobic conditions (EFSA, 2005). Mercurio et al. (2016) reported that the $\mathrm{DT}_{50}$ of DUR in water was 499 days in a dark environment, suggesting very slow natural degradation rates. Several reports have confirmed that DUR enters the surface water and groundwater through irrigation, drainage, percolation, and surface runoff (Camenzuli et al., 2012; Moisset et al., 2015; Maqbool et al., 2016), as shown in Figure 1.

The residues of DUR are mainly distributed within the most superficial layer of the topsoil, seldom leaching from the upper $10 \mathrm{~cm}$ of surface soil, with no residues detected at depths greater than $70 \mathrm{~cm}$. DUR concentration tends to decline with soil depth (Tworkoski et al., 2000; Landry et al., 2006), as shown in Figure 2. The sorption of non-ionic organic compounds in the soil is usually expressed as the sorption coefficient $\left(K_{\mathrm{D}}\right)$, reflecting the dissipation dynamics of xenobiotics in the environment. Dages et al. (2015) reported that the $K_{\mathrm{D}}$ of DUR decreased from $13.93 \mathrm{~mL} / \mathrm{g}$ to $3.57 \mathrm{~mL} / \mathrm{g}$ from the upper soil $(0-17 \mathrm{~cm})$ to deeper soil $(45-80 \mathrm{~cm})$; a similar value was reported by a 


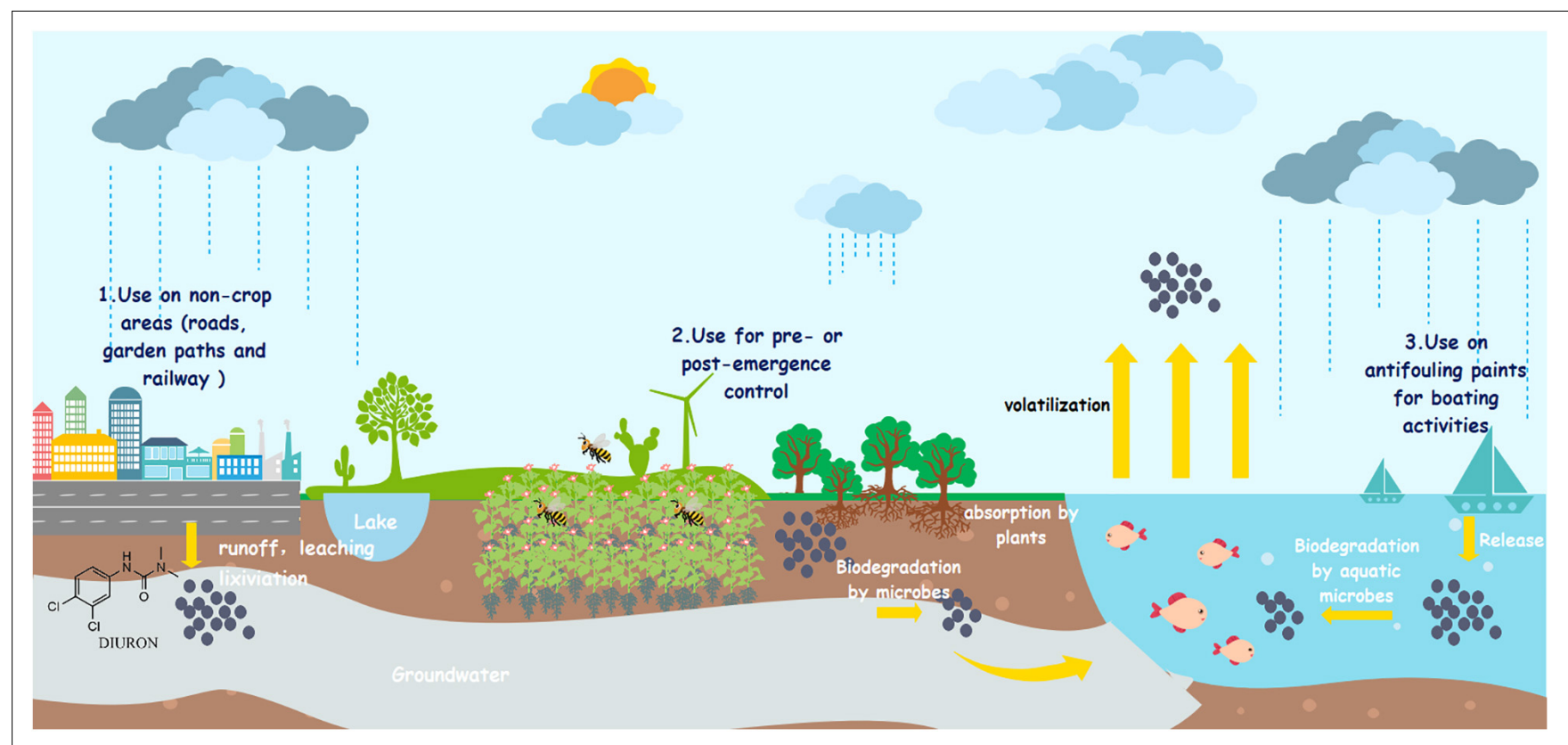

FIGURE 1 | Fate and occurrence of diuron into the environment. (1) Diuron enters groundwater through leaching. (2) Diuron enters surface water through runoffs. (3) Diuron enters atmosphere through volatilization.

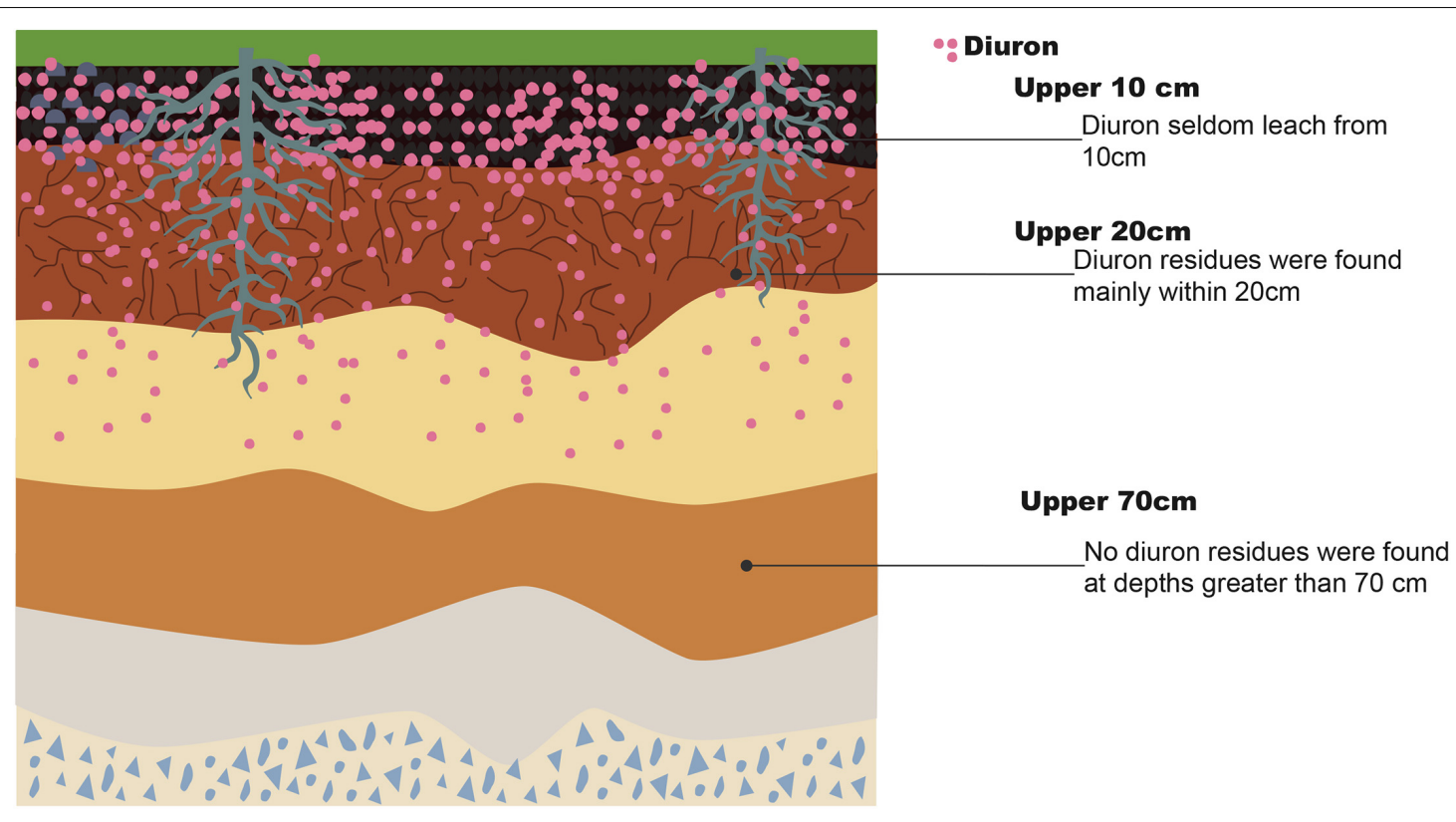

FIGURE 2 | Distribution of diuron in upper soil.

previous study (Dores et al., 2009). DUR is considered weakly to moderately mobile, being strongly retained in the topsoil but less retained in deeper regions. Dos Reis et al. (2017) reported that $96.1 \%$ of DUR remained in the $0-5-\mathrm{cm}$ soil layer after a rainfall simulation, whereas only $0.91 \%$ remained in the $5-10-\mathrm{cm}$ soil layer, confirming its low mobility through the soil profile. DUR mobility is related to soil organic carbon content and soil texture (Landry et al., 2006). Tandon and Pant (2019) found that the persistence of DUR was stronger in sandy loam than in silty clay loam soil in sugarcane fields. The $\mathrm{DT}_{50}$ of DUR in silty clay loam soil was 32.37 days when applied at $4 \mathrm{~kg} / \mathrm{ha}$, whereas it was 43.93 days in sandy loam soil. Dias Guimaraes et al. (2018) found that among the three types of soil, namely, sand, clay, and loam, which had been exposed to herbicides for the past 3 years, the $\mathrm{DT}_{50}$ of loam soil was the lowest (97.63 days). Loam soil showed the highest cation exchange 
capacity among the three types of soil; therefore, the benefit to growth activity and life of microorganisms due to the availability of more nutrients increases DUR degradation. When herbicides are converted to bound residues (non-extractable residues), they become unavailable for biodegradation by microorganisms. They also determined that the bound residues of DUR accounted for $38.65-42.54 \%$ of the initial amount (3.32 a.i. $\mathrm{g}^{-1}$ of soil) at 70 days after treatment. The DUR metabolites DCPMU and 3,4dichlorophenylurea (DCPU) were also found in the soil. This is possibly due to its high microbial activity, as the $0-2.5-\mathrm{cm}$ surface soil with grass cover contained a large amount of DCPMU, where DCPMU migrated to a depth of $10-20 \mathrm{~cm}$ in the soil (Landry et al., 2006). DCPMU was detected at a depth of $40 \mathrm{~cm}$ in natural calcareous soils (Field et al., 2003).

Diuron is frequently detected in rivers, streams, lakes, and seawater because of its high water solubility $(42 \mathrm{mg} / \mathrm{L})$ and long aqueous photolysis half-life (Felício et al., 2018; Akcha et al., 2020). Loos et al. (2009) reported that approximately $70 \%$ of the samples from European streams contained the maximum concentration of DUR (864 ng/L). In the Mediterranean and in Australia, stream waters and suspended sediments transport pesticides from agricultural areas to coastal lagoons and wetlands, leading to the accumulation of active ingredients in the sediments (Moreno-González and León, 2017; Mendez et al., 2018). Landry et al. (2006) showed that the vineyards of Burgundy were contaminated with DUR residues. They also detected greater quantities of DCPMU than DCPUs in the percolates, especially after rainfall. In Costa Rica river basins, the highest DUR concentrations in water and sediment samples were $22.8 \mu \mathrm{g} / \mathrm{L}$ and $11.75 \mu \mathrm{g} / \mathrm{kg}$, respectively. Many studies have indicated that the risk is unacceptable even under a conservative scenario and suggested a high degree of acute toxicity to the ecosystem (Carazo-Rojas et al., 2018; Viana et al., 2019). In the Galápagos Islands, one of the last frontiers for conducting ecotoxicology research (UNESCO World Heritage region), the concentration of DUR $(1.61 \mu \mathrm{g} / \mathrm{L})$ between the two islands was the highest in samples from coastal waters in urban areas. Riascos-Flores et al. (2020) showed that this concentration $(1.61 \mu \mathrm{g} / \mathrm{L})$ poses a high risk for three groups of organisms: algae, invertebrates, and fishes.

\section{Direct and Indirect Effect on Aquatic Organisms, Mammals, and Humans}

Numerous non-target organisms, such as bacteria, phytoplankton, invertebrates, fish, mammals, and humans, suffer from the deleterious effects of xenobiotics (Giacomazzi and Cochet, 2004; Dupraz et al., 2016). As photosystem II and its conservation in plants are the targets of DUR, non-target phytoplankton is equally affected, such as seagrass and corals (Marques et al., 2020; Thomas et al., 2020). Plants eventually die due to long-term starvation under moderate irradiation (electron transfer rate inhibition) or oxidative stress under higher levels of radiation (Diepens et al., 2017; Wilkinson et al., 2017). Over the past decade, a large volume of published studies has described the toxic effects of DUR on green algae and seagrass in tropical marine environments (King et al., 2013;
Negri et al., 2015; Diepens et al., 2017; Brodie and Landos, 2019; Thomas et al., 2020). Negri et al. (2015) reported 7-day IC $_{50}$ values (concentrations inhibiting quantum yield by 50\%) of 2.7 and $3.8 \mu \mathrm{g} / \mathrm{L}$ for DUR on the growth of two tropical seagrass species, Zostera muelleri and Halodule uninervis, respectively. Moreover, phytoplankton could suffer from an additive toxicity effect with other adverse factors, such as ocean warming and ocean acidification (Marques et al., 2020). van Dam et al. (2015) conducted co-exposure experiments, revealing that the inhibition of photosynthetic yield under DUR and thermal stress is additive. In addition, the ocean contains other pesticide-active ingredients that can also cause additional toxic effects on phytoplankton. Mercurio et al. (2018) evaluated the potential toxicity of photosystem II herbicide metabolites to coral symbionts (Symbiodinium sp.) and found that the toxicity of 3,4-DCA was greater than that of DUR. Likewise, Sigurnjak et al. (2020) revealed additive toxicity effects on freeze-dried Vibrio fischeri when DUR was combined with alachlor, chlorfenvinphos, and isoproturon.

Recently, investigators have examined the effects of DUR on fish and invertebrates. For example, Akcha et al. (2020) showed the genotoxicity of DUR through DNA damage and a decrease in DNA methylation levels in oysters. Boscolo et al. (2018) showed that the biotransformation of DUR to its active metabolites affects neurotransmitters in Nile tilapia. Similarly, Perissini-Lopes et al. (2016) reported that the DUR metabolites, 3,4-DCA, DCPU, and DCPMU, have antiandrogen activity in Nile tilapia, potentially causing reproductive disorders in male fish.

Indeed, it is evident that phenylurea herbicides (PUHs) have relatively low acute toxicity to mammals, birds, and fish compared with plants, algae, and invertebrates. However, at sufficiently high concentrations, DUR was shown to have toxic effects on fetal development in mammals, birds, and humans (Huovinen et al., 2015; Eletto et al., 2020). Several studies have demonstrated that DUR is carcinogenic to the rat urothelium (Fernandes et al., 2007; da Rocha et al., 2013; Ihlaseh-Catalano et al., 2014). Huovinen et al. (2015) and Eletto et al. (2020) found that it had cytotoxic effects on human primary urothelial cells at high concentrations and elucidated the molecular mechanisms involved in this process. Mohammed et al. (2018) detected that DUR can penetrate the human placenta and metabolize it to DCPMU at a high concentration $(100 \mu \mathrm{M})$. This suggests that pregnant women can suffer fetotoxicity if they are exposed to DUR. Mohammed et al. (2020) indicated that DUR metabolites are more toxic than the parent compound in human cells, with the mitochondria as their target. Concerning the effects of chronic exposure to herbicides and the mechanisms involved, several questions regarding ecotoxicology remain to be addressed (Akcha et al., 2020).

\section{DIURON-DEGRADING MICROORGANISMS}

\section{Axenic Cultures for Diuron Degradation}

In recent years, the use of biological resources, especially microbes, to degrade DUR has emerged as a powerful tool for 
its degradation and remediation in situ (Bhatt et al., 2021a,c; Zhang et al., 2021). DUR is susceptible to microbial degradation, and aquatic microorganisms enriched in pond water can also degrade DUR to one of its major metabolites, 3,4DCA (Richards et al., 2020). The first known bacterial strain capable of mineralizing DUR, Variovorax sp. SRS16, was isolated by Sorensen et al. (2008). This bacterial strain was also the first bacterium capable of mineralizing both the $N, N$-dimethyl-substituted PUH, linuron, and the $N$-methoxy$N$-methyl-substituted PUH, DUR. Currently, a number of DUR-degrading bacteria and fungi have been screened, enriched, and cultivated, including the organisms from the genera Pseudomonas, Stenotrophomonas, Arthrobacter, Burkholderia, Vagococcus, Bacillus, and Micrococcus (Table 1) and the fungal genera Pycnoporus, Pluteus, Trametes, Neurospora, Cunninghamella, Aspergillus, and Mortierella (Table 2). To date, only a few bacterial strains capable of mineralizing DUR or simultaneously degrading DUR and 3,4-DCA have been reported (Sharma et al., 2010; Ellegaard-Jensen et al., 2013; Villaverde et al., 2017), as most isolates catabolize DUR to DCPMU, DCMU, or 3,4-DCA. Arthrobacter sp. BS1, BS2, and SED1 can transform DUR to 3,4-DCA, whereas Achromobacter sp. SP1 was able to degrade 3,4-DCA through cooperative microbial transformation. An artificial consortium comprising BS2 and SP1 was able to completely mineralize DUR within 5 days (Devers-Lamrani et al., 2014).

Enrichment culture is an important step for scanning DUR degraders, as most degrading microorganisms have been isolated from the soil, sediment, and agricultural fields (Ellegaard-Jensen et al., 2014; Villaverde et al., 2017, 2018). In addition, isolation from plant rhizosphere, roots, or decaying plant tissues is being increasingly recognized as an important

TABLE 1 | Newly isolated diuron-degrading bacteria.

\begin{tabular}{|c|c|c|c|c|}
\hline Strains & Findings & Intermediates & Sources & References \\
\hline Micrococcus sp. PS-1 & $\begin{array}{l}96 \% \text { of diuron }(250 \mathrm{mg} / \mathrm{L}) \\
\text { was degraded in } 30 \mathrm{~h}\end{array}$ & $\begin{array}{c}\text { 3,4-DCA, 1,2-DCB, 4,5-DCC, } \\
\text { 3,4-DCHD, 3-COHDA }\end{array}$ & $\begin{array}{l}\text { Soil from diuron storage site, } \\
\text { Ankleshwar, India }\end{array}$ & Sharma et al., 2010 \\
\hline $\begin{array}{l}\text { Bacillus cereus, Vagococcus fluvialis, } \\
\text { Burkholderia ambifaria, Bacillus spp. }\end{array}$ & $\begin{array}{l}21,25,22 \text {, and } 19 \% \text {, of } \\
\text { diuron ( } 40 \mathrm{mg} / \mathrm{L}) \text { was degraded } \\
\text { in } 35 \text { days, respectively }\end{array}$ & DCPMU, 3,4-DCA & Sugarcane-cultivated fields, Kenya & Ngigi et al., 2011 \\
\hline Arthrobacter sp. BS2 & $\begin{array}{c}100 \% \text { of diuron }(30 \mathrm{mg} / \mathrm{L}) \\
\text { was degraded in } 24 \mathrm{~h}\end{array}$ & $3,4-\mathrm{DCA}$ & Soil and sediments, France & $\begin{array}{l}\text { Devers-Lamrani } \\
\text { et al., } 2014\end{array}$ \\
\hline Arthrobacter sp. BS1, SED1 & $\begin{array}{l}100 \% \text { of diuron }(50 \mathrm{mg} / \mathrm{L}) \\
\text { was degraded in } 5 \text { days }\end{array}$ & $3,4-D C A$ & Soil and sediments, France & $\begin{array}{l}\text { Devers-Lamrani } \\
\text { et al., } 2014\end{array}$ \\
\hline Bacillus licheniformis SDS12 & $\begin{array}{l}85.6 \% \text { of diuron }(50 \mathrm{mg} / \mathrm{L}) \\
\text { was degraded in } 10 \text { days }\end{array}$ & $\begin{array}{c}\text { 3,4-DCA, 1,2-DCB, 4,5-DCC, } \\
\text { 3,4-DCHD, 3-COHDA }\end{array}$ & Parthenium endophyte, India & $\begin{array}{l}\text { Singh and Singla, } \\
2019\end{array}$ \\
\hline Stenotrophomonas rhizophila CASB3 & $\begin{array}{l}94 \% \text { of diuron ( } 50 \mathrm{mg} / \mathrm{L}) \\
\text { was degraded in } 42 \text { days }\end{array}$ & $\begin{array}{l}\text { 3,4-DCA, 4-CA, aniline, } \\
\text { catechol }\end{array}$ & $\begin{array}{c}\text { Endophyte from roots of Fragaria } \\
\text { ananassa plants, Chile }\end{array}$ & $\begin{array}{l}\text { Silambarasan et al., } \\
2020\end{array}$ \\
\hline Pseudomonas aeruginosa FN & $\begin{array}{l}54 \% \text { of diuron }(10 \mathrm{mg} / \mathrm{L}) \\
\text { was degraded in } 6 \mathrm{~h}\end{array}$ & $3,4-\mathrm{DCA}$ & Tobacco waste, Croatia & Grgić et al., 2020 \\
\hline $\begin{array}{l}\text { Bacillus pseudomycoides D/T, Bacillus } \\
\text { simplex/Bacillus muralis D/N }\end{array}$ & $\begin{array}{c}54 \text { and } 51 \% \text { of diuron } \\
\text { ( } 50 \mathrm{mg} / \mathrm{L} \text { ) was degraded in } \\
46 \text { days, respectively }\end{array}$ & DCPMU, 3,4-DCA & $\begin{array}{c}\text { Diuron contaminated sugarcane } \\
\text { and pineapple-cultivated soils, } \\
\text { Kenya }\end{array}$ & $\begin{array}{l}\text { Muendo et al., } \\
2021\end{array}$ \\
\hline
\end{tabular}

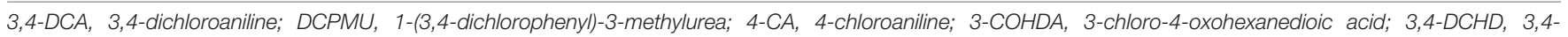
dichlorohex-3-ene-1,6-diol; 4,5-DCC, 4.5-dichlorocatechol; 1,2-DCB, 1,2-dichlorobenzene; DCPU, 1-(3,4-Dichlorophenyl) urea.

TABLE 2 | Newly isolated diuron-degrading fungi.

\begin{tabular}{|c|c|c|c|c|}
\hline Strains & Findings & Intermediates & Sources & References \\
\hline Mortierella sp. LEJ701 and LEJ702 & $\begin{array}{l}100,33.6 \% \text { of diuron }(5 \mathrm{mg} / \mathrm{L}) \text { was } \\
\text { degraded in } 43 \text { days, respectively }\end{array}$ & DCPMU, DCPU, DCPMDU & Agricultural field, Denmark & $\begin{array}{l}\text { Ellegaard-Jensen } \\
\text { et al., } 2013\end{array}$ \\
\hline $\begin{array}{l}\text { Aspergillus brasiliensis G08, Aspergillus } \\
\text { sp. G25, and Cunninghamella elegans } \\
\text { B06 }\end{array}$ & $\begin{array}{l}81.3,84.6 \text {, and } 67.0 \% \text { of diuron } \\
(10 \mathrm{mg} / \mathrm{L}) \text { was degraded in } 5 \text { days }\end{array}$ & DCPMU, DCPU, 3,4-DCA & $\begin{array}{c}\text { Sugarcane-cultivated fields, } \\
\text { Brazil }\end{array}$ & $\begin{array}{c}\text { Egea et al., 2014; } \\
\text { Perissini-Lopes } \\
\text { et al., } 2016\end{array}$ \\
\hline Neurospora intermedia DP8-1 & $\begin{array}{l}\text { 99\% of diuron ( } 50 \mathrm{mg} / \mathrm{L}) \text { was } \\
\text { degraded in } 3 \text { days }\end{array}$ & DCPMU, DCPU & $\begin{array}{l}\text { Endophyte from sugarcane } \\
\text { root, China }\end{array}$ & Wang et al., 2017 \\
\hline Trametes versicolor K-41 & $\begin{array}{l}\text { 98.7\% of diuron }(1 \mu \mathrm{M}) \text { was } \\
\text { degraded in } 14 \text { days }\end{array}$ & DCPMU, DCPU, 3,4-DCA & $\begin{array}{l}\text { Natural decayed wood, } \\
\text { Japan, }\end{array}$ & Mori et al., 2018 \\
\hline Pluteus cubensis SXS 320 & $\begin{array}{l}96.8 \% \text { of diuron }(25 \mathrm{mg} / \mathrm{L}) \text { was } \\
\text { degraded in } 20 \text { days }\end{array}$ & DCPMU, DCPU, 3,4-DCA & Decaying wood, Brazil & Henn et al., 2020 \\
\hline Pycnoporus sanguineus MCA 16 & $\begin{array}{l}56 \% \text { of diuron ( } 25 \mathrm{mg} / \mathrm{L}) \text { was } \\
\text { degraded in } 40 \text { days }\end{array}$ & DCPMU, DCPU, 3,4-DCA & Decaying wood, Brazil & Henn et al., 2020 \\
\hline
\end{tabular}

DCPMU, 1-(3,4-dichlorophenyl)-3-methylurea; DCPU, 1-(3,4-dichlorophenyl) urea; DCPMDU, 1-(3,4-dichlorophenyl)-3-methylideneurea; 3,4-DCA, 3,4-dichloroaniline. 
source of DUR-degrading microorganisms (Bhatt et al., 2020; Huang et al., 2020; Pang et al., 2020). For example, some endophytes capable of degrading DUR have been isolated from plant roots (Wang et al., 2017; Grgić et al., 2020), which may have evolved mechanisms to degrade toxic pollutants into benign forms (Singh and Singla, 2019). For example, Wang et al. (2017) isolated an endophyte, Neurospora intermedia strain DP8-1, from sugarcane. The removal rate of this endophyte for DUR in an aqueous medium was $99 \%$ within 3 days; in sterile soil, it was $41.92 \%$ within 20 days, and it was mainly metabolized to DCPMU and DCPU.

Moreover, plant growth-promoting rhizobacteria have played a positive role in the degradation of herbicides in agricultural soils. Silambarasan et al. (2020) isolated Stenotrophomonas rhizophila strain CASB3, which reached a degradation rate of $94 \%$ within 42 days from an initial concentration of $50 \mathrm{mg} / \mathrm{L} \mathrm{DUR}$, and simultaneously enhanced the root-shoot length, fresh-dry biomass, and photosynthetic pigments in Lactuca sativa plants, which also showed their ability to degrade DUR under saline stress conditions. Similarly, Singh and Singla (2019) isolated five DUR-degrading endophyte strains with PGP traits. The degradation rate of $50 \mathrm{mg} / \mathrm{L}$ DUR by Bacillus licheniformis strain SDS12 was $85.6 \%$ within 10 days.

Fungi have also been widely used in the biodegradation and bioremediation of DUR. White-rot fungi have great potential for degrading DUR due to their high levels of enzyme activity, including extracellular ligninolytic enzymes, intracellular cytochrome P450 monooxygenases, and antioxidant enzymes (Coelho-Moreira et al., 2018; Mori et al., 2018; Hu et al., 2020). Some white-rot fungi degrade DUR to DCPMU and DCPU and do not accumulate the metabolite 3,4-DCA (Ellegaard-Jensen et al., 2013; Coelho-Moreira et al., 2018). Mori et al. (2018) found that the white-rot fungus Trametes versicolor K-41 could utilize 3,4-DCA as its sole carbon and energy source in an aqueous medium. There may be a mechanism involved in the rapid degradation of 3,4-DCA, protecting fungi from high toxicity, or there might be a new metabolic pathway involved in this phenomenon.

\section{Consortium-Based Removal of Diuron}

The isolation and purification of microorganisms capable of degrading PUHs have often failed, partly because of the requirement of catabolic cooperation between microbial populations of bacterial consortia (Sørensen et al., 2002; Bhatt et al., 2021d; Huang et al., 2021). In addition, complementary catabolism between synergistic species in a consortium seldom leaves harmful intermediates (Zhang et al., 2018, 2020). Sphingomonas sp. SRS2 is auxotrophic, meaning it requires nutrition from other microorganisms. Therefore, strain SRS2 uses the amino acids supplied by strain SRS1, leading to the corresponding growth of strain SRS2 and the rapid metabolism of isoproturon to carbon dioxide $\left(\mathrm{CO}_{2}\right)$ (Sørensen et al., 2002). Villaverde et al. (2017) found that a consortium composed of three DUR degraders, Arthrobacter sulphonivorans, Variovorax soli, and Advenella sp. JRO completed DUR mineralization after only a few days. When combined in pairs, they mineralized $40 \%$ of DUR in solution; however, none of the three strains individually mineralized DUR. By consuming excretion products from Comamonas testosteroni WDL7 and/or Hyphomicrobium sulfonivorans WDL6, Variovorax sp. WDL1 can indirectly obtain carbon and nutrients from linuron (Albers et al., 2018). They observed that the linuron hydrolase gene hylA in WDL1 was expressed over 100-fold higher in a consortium condition. Zhang et al. (2018) isolated a consortium that achieved complete metabolism of DUR. Diaphorobacter sp. strain LR2014-1 initially degraded linuron to 3,4-DCA, whereas Achromobacter sp. strain ANB-1 further mineralized 3,4-DCA to $\mathrm{CO}_{2}$. In addition to the original syntrophic consortia described earlier, a considerable number of recent studies have used artificially composed consortia to degrade PUHs. Sorensen et al. (2008) conducted an experiment using a linuron degrader (Variovorax sp. SRS16) and a DUR degrader (Arthrobacter globiformis D47) and found that neither of them individually mineralized DUR in a liquid medium, but when combined, the consortium mineralized 31$62 \%$ of DUR to $\mathrm{CO}_{2}$. A consortium composed of bacteria (Sphingomonas sp., Variovorax sp., and A. globiformis) and fungi (Mortierella sp. LEJ702 and LEJ703) achieved complete mineralization of DUR in sand (Ellegaard-Jensen et al., 2014). The DUR degrader Arthrobacter sp. BS2 and 3,4-DCA degrader Achromobacter sp. SP1 were artificially combined and were able to entirely dissipate DUR within $35 \mathrm{~h}$ (Devers-Lamrani et al., 2014). On the other hand, Dejonghe et al. (2003) showed that the degradation rate of linuron by an artificial consortium was lower than that of the original consortium, possibly because species had a lower abundance in the artificial consortium. According to Zhang et al. (2018), functional species are not always the predominant species in a community. Strains LR2014$1(0.33 \%)$ and ANB-1 (0.77\%) can hydrolyze linuron to 3,4DCA and mineralize 3,4-DCA but only at a low abundance in a consortium.

\section{MICROBIAL DEGRADATION PATHWAYS AND MECHANISMS}

Microbial metabolism accounts for a large proportion of the degradation and natural attenuation of DUR in the environment. The degradation pathways of DUR in microorganisms are summarized in Figure 3. First, DUR degrades into one or two $N$-demethylations of a urea group and generates two metabolites, DCPMU and DCPU, respectively. This is followed by the hydrolysis of the amide bond, generating the metabolite 3,4-DCA, which is the common microbial DUR degradation product (Giacomazzi and Cochet, 2004; Egea et al., 2017; Silambarasan et al., 2020). Studies have also shown that some strains directly transform DUR to DCPU or 3,4-DCA without the formation of other intermediates (Cui et al., 2014; Hussain et al., 2015). Hydrolysis of amide bonds to produce 3,4-DCA is a key enzymatic step in the degradation of DUR (Hussain et al., 2015). According to the current literature, 3,4-DCA degradation mainly proceeds through two different metabolic pathways: dehalogenation and hydroxylation. The first biodegradation pathway of 3,4-DCA proceeds via direct oxidative deamination to form 1,2-dichlorobenzene and subsequent ortho-cleavage of 


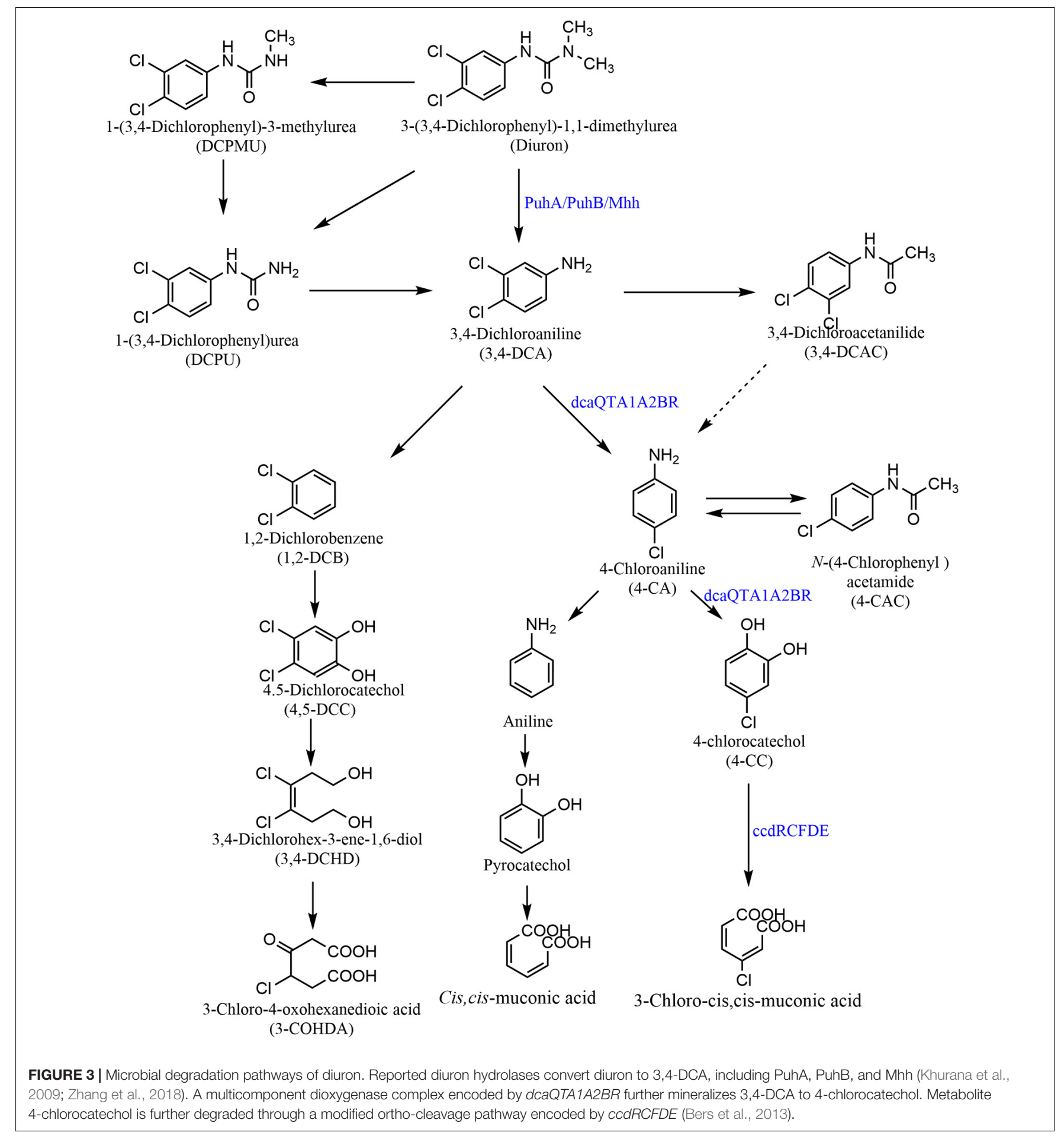

the resulting 4,5-dichlorocatechol, followed by the phenyl ring breakage of 4,5-dichlorocatechol to produce 3,4dichlorohex-3-ene-1,6-diol and 3-chloro-4-oxohexanedioic acid. 3-Chloro-4-oxohexanedioic acid subsequently enters the succinic acid degradation pathway, which has been reported by Sharma et al. (2010) and Singh and Singla (2019). The second biodegradation pathway of 3,4-DCA is via dechlorination from the aromatic ring and the generation of the mono-chlorinated aniline, 4-chloroaniline (4-CA) (Silambarasan et al., 2020). Degradation of 4-CA also proceeds through two different pathways: dechlorination and deoxygenation, forming aniline and 4-chlorocatechol, respectively. According to Hongsawat and Vangnai (2011), Acinetobacter baylyi GFJ2 can catabolize 4-CA through both these pathways, and 
after that, aniline deamination, to generate catechol. Then, ortho-cleavage of the phenyl ring leads to the accumulation of cis,cis-muconic acid and 3-chloro-cis,cis-muconic acid, respectively, in the pyrocatechol and 4-chlorocatechol pathways. However, Egea et al. (2017) and Silambarasan et al. (2020) showed that catechol is the final metabolite after the deamination of aniline. Ellegaard-Jensen et al. $(2013,2014)$ and PerissiniLopes et al. (2016) found that some fungi, including Mortierella isabellina, Aspergillus brasiliensis G08, Cunninghamella elegans B06, Mortierella sp. LEJ702, and A. globiformis D47, metabolize 3,4-DCA to 3,4-dichloroacetanilide (3,4-DCAA). These results are similar to those reported by Tixier et al. (2002). Although this process does not achieve complete mineralization, toxicity is reduced, as 3,4-DCAA is less toxic than 3,4-DCA (Tixier et al., 2002). According to Egea et al. (2017), some isolates act on 3,4-DCA and 4-CA to form 3,4-DCAA and N-(4-chlorophenyl) acetamide via alkylation and dealkylation. However, Micrococcus luteus and Achromobacter sp. act on 3,4-DCA and dehalogenate it directly to aniline. DUR is metabolized via a different pathway under anaerobic conditions, and Attaway et al. (1982) detected the accumulation of 3-(3-chlorophenyl)-1-1dimethylurea through this mechanism. However, Stasinakis et al. (2009) indicated that DCPU is the major metabolite under anoxic conditions. Three intermediate metabolites, DCPMU, DCPU, and DCA, were detected under aerobic conditions, but only DCPU was detected under anoxic conditions, which exhibited a longer half-life (92 vs. 35 days under aerobic conditions) (Shareef et al., 2014). However, there is little published information on the DUR degradation pathway under anaerobic conditions.

Although the DUR degradation pathway has been partly elucidated, the complete metabolic pathway and the genes and enzymes involved in metabolism remain to be discovered. Advanced omics-based approaches will serve as the baseline information for genetic engineering leading to DUR degradation. The sequence information obtained through these approaches could be used to identify potential hosts and study gene exchanges in bacterial populations. The mechanism involved in these strains also requires further investigation.

\section{FUNCTIONAL ENZYMES AND GENES INVOLVED IN DIURON DEGRADATION}

Many different enzymatic processes are involved in biodegradation by microorganisms, including hydroxylation, demethylation, dechlorination, and oxidation (Liu et al., 2020; Bhatt et al., 2021e). Different biodegradation processes are associated with different enzymes, such as hydrolases, esterases, dehydrogenases, laccases, and lignin peroxidases (Maqbool et al., 2016; Lin et al., 2020; Mishra et al., 2020). The reported enzymes involved in the initial degradation of PUHs are amidohydrolases or amidases, which are summarized in Table 3, and a phylogenetic tree (amino acid sequences) of the key initial hydrolytic enzymes is shown in Figure 4.

The first purified phenylurea hydrolase was obtained in 1971 from Bacillus sphaericus, which catalyzes the breakdown of
$N$-methoxy- $N$-methyl phenylureas (OMs), but not DUR or other N,N-dimethyl phenylureas (DMs) (Engelhardt et al., 1971, 1973). Genetic characterization of the first DUR-degrading enzyme, PuhA, was performed by Turnbull et al. (2001). After this, PuhB (Khurana et al., 2009), LibA (Bers et al., 2012), HylA (Bers et al., 2013), Phh, Mhh (Zhang et al., 2018), and LahB (Zhang et al., 2020) were identified (Table 3). They can all transform PUHs into 3,4-DCA. PuhA and PuhB were identified in the DUR degraders A. globiformis D47 and Mycobacterium brisbanense JK1, respectively. In fact, despite both PuhA and PuhB being isolated from DUR-degrading bacteria, the catalytic efficiency of these two enzymes for linuron was relatively high, and they also hydrolyzed both DM and OM PUHs (Khurana et al., 2009). PuhA and PuhB were discovered in separate continents, which makes it challenging to elucidate the evolutionary origins of these enzymes. Horizontal gene transfer through genetic elements, such as plasmids and transposons, is a possible way to spread phenylurea-degrading genes. Dunon et al. (2013) reported that the number of insertion sequence IS1071 gene copies increased substantially after phenylurea treatment, indicating that horizontal gene transfer might occur in these degraders. However, Ozturk et al. (2020) analyzed the full-genome sequences of six Variovorax strains capable of degrading linuron, which were isolated from geographically distant locations. This result indicates that it is unlikely that they originated from a common ancestral linuron degrader, in contrast with the $s$-triazine degraders whose degradation genes are spread in a variety of bacterial populations (Wackett et al., 2002). LibA, which was identified in the linuron-degrading Variovorax sp. SRS16, has high specificity and only hydrolyzes linuron (Bers et al., 2011). Strain SRS16 was the first bacterium for which the genetic organization of the complete mineralization pathway of a PUH has been established. In SRS16, the enzymes dcaQTA $_{1} \mathrm{~A}_{2} \mathrm{~B}$ (deoxygenation of DCA to chlorocatechol) and ccdCDEF (chlorocatechol ortho-cleavage) are involved in the transformation of dicholoroaniline to oxo-adipate. HylA was also identified in the Variovorax genus and could only hydrolyze $N$-methoxy- $N$-methyl-substituted phenylureas, including linuron, monolinuron, and metobromuron (Bers et al., 2013).

Recently, Zhang et al. (2018, 2020) identified the enzymes Phh and Mhh (from Diaphorobacter sp. LR2014-1) and LahB (Sphingobium sp. SMB). Phh and Mhh functioned in the complementary hydrolysis of PUHs, enabling strain LR2014-1 to hydrolyze both DM and OM PUHs (Zhang et al., 2018). Interestingly, Phh and Mhh are evolutionarily divergent. The new PUH-degrading enzyme LahB, which is similar to LibA, can only hydrolyze linuron and exhibits a narrow substrate spectrum (Zhang et al., 2020). Among these seven enzymes, HylA belongs to the YctJ-like family within the metal-dependent amidohydrolase superfamily. PuhA, PuhB, Phh, and LahB are members of this superfamily, whereas LibA and Mhh belong to the amidase superfamily (Khurana et al., 2009; Bers et al., 2012, 2013; Zhang et al., 2018, 2020).

Apart from these six hydrolases, recent studies have indicated that other novel DUR enzymes may exist in the environment. Coelho-Moreira et al. (2018) and $\mathrm{Hu}$ et al. (2020) found 
TABLE 3 | Phenylurea herbicide initial hydrolysis enzymes.

\begin{tabular}{|c|c|c|c|c|c|c|c|}
\hline Enzymes & Type & $\begin{array}{c}\text { GenBank } \\
\text { accession No. }\end{array}$ & $\begin{array}{l}\text { Degraded } \\
\text { herbicides }\end{array}$ & Biochemical conditions & Host strains & $\begin{array}{l}\text { Host strain } \\
\text { sources }\end{array}$ & References \\
\hline PuhA & $\begin{array}{l}\text { Metal-dependent hydrolase } \\
\text { subfamily, amidohydrolase } \\
\text { superfamily }\end{array}$ & ACL11849.1 & $\mathrm{DM}$ and $\mathrm{OM}$ & $\begin{array}{c}\mathrm{pH} 6.5-8.5 \text {, Temp } 30-35^{\circ} \mathrm{C}, K_{\mathrm{m}} \\
55.0 \pm 19.1 \mu \mathrm{M} \text { (for diuron, } \\
\text { different } K_{\mathrm{m}} \text { calculated for all the } \\
\text { substrates), MW } 48.9 \mathrm{KDa} \text {, pl } 5.2\end{array}$ & $\begin{array}{c}\text { Arthrobacter } \\
\text { globiformis D47 }\end{array}$ & $\begin{array}{l}\text { Isoproturon-treated } \\
\text { cereal-growing } \\
\text { areas, } \\
\text { United Kingdom }\end{array}$ & $\begin{array}{l}\text { Cullington and } \\
\text { Walker, 1999; } \\
\text { Turnbull et al., } \\
\text { 2001; Khurana } \\
\text { et al., } 2009\end{array}$ \\
\hline PuhB & $\begin{array}{l}\text { Metal-dependent hydrolase } \\
\text { subfamily, amidohydrolase } \\
\text { superfamily }\end{array}$ & ACL11830.1 & $\mathrm{DM}$ and $\mathrm{OM}$ & $\begin{array}{c}\mathrm{pH} \text { 6.5-8.5, Temp } 30-35^{\circ} \mathrm{C}, K_{\mathrm{m}} \\
11.0 \pm 2.8 \mu \mathrm{M} \text { (for diuron, different } \\
K_{\mathrm{m}} \text { calculated for all the } \\
\text { substrates), MW } 49.5 \mathrm{KDa}\end{array}$ & $\begin{array}{l}\text { Mycobacterium } \\
\text { brisbanense JK1 }\end{array}$ & $\begin{array}{l}\text { Diuron-treated } \\
\text { sugarcane-growing } \\
\text { areas, Australia }\end{array}$ & $\begin{array}{l}\text { Khurana et al., } \\
\qquad 2009\end{array}$ \\
\hline LibA & Amidase superfamily & AEO20132.1 & Linuron & $\begin{array}{c}\text { Temp } 22-30^{\circ} \mathrm{C}, K_{m} 5.8 \mu \mathrm{M}, \mathrm{MW} \\
55 \mathrm{KDa}\end{array}$ & $\begin{array}{l}\text { Variovorax } \\
\text { sp. SRS16 }\end{array}$ & $\begin{array}{l}\text { Agricultural soil, } \\
\text { Denmark }\end{array}$ & $\begin{array}{l}\text { Sørensen et al., } \\
\text { 2005; Bers et al., } \\
2012\end{array}$ \\
\hline HylA & $\begin{array}{l}\text { Yctj-like family, } \\
\text { metal-dependent hydrolase } \\
\text { subfamily, amidohydrolase } \\
\text { superfamily }\end{array}$ & AGF25452.1 & $\mathrm{OM}$ & $\begin{array}{c}\text { Temp } 35^{\circ} \mathrm{C}, K_{m} 15.0 \pm 0.8 \mu \mathrm{M} \text { (for } \\
\text { linuron), MW } 56 \mathrm{KDa}\end{array}$ & $\begin{array}{l}\text { Variovorax } \\
\text { sp. WDL1 }\end{array}$ & $\begin{array}{l}\text { Herbicide treatment } \\
\text { soil, Belgium }\end{array}$ & $\begin{array}{l}\text { Dejonghe et al., } \\
\text { 2003; Bers et al., } \\
2013\end{array}$ \\
\hline Phh & $\begin{array}{l}\text { Metal-dependent hydrolase } \\
\text { subfamily, amidohydrolase } \\
\text { superfamily }\end{array}$ & ANU78861.1 & DM and OM & $\begin{array}{c}\mathrm{pH} \text { 7.0-8.0, Temp } 33-37^{\circ} \mathrm{C}, K_{\mathrm{m}} \\
235.4 \pm 37 \mu \mathrm{M} \text { (for diuron, different } \\
K_{\mathrm{m}} \text { calculated for all the } \\
\text { substrates), MW } 49.5 \mathrm{KDa}\end{array}$ & $\begin{array}{l}\text { Diaphorobacter } \\
\text { sp. LR2014-1 }\end{array}$ & $\begin{array}{l}\text { A disused pesticide } \\
\text { factory, China }\end{array}$ & Zhang et al., 2018 \\
\hline Mhh & Amidase superfamily & ANU78862.1 & $\begin{array}{l}\text { Linuron and } \\
\text { duron }\end{array}$ & $\begin{array}{c}\mathrm{pH} 7.5, \text { Temp } 35^{\circ} \mathrm{C}, \mathrm{K}_{\mathrm{m}} \\
28.8 \pm 1.7 \mu \mathrm{M}, 21.5 \pm 1.2 \mu \mathrm{M} \text { (for } \\
\text { linuron and siduron), MW } 50 \mathrm{KDa}\end{array}$ & $\begin{array}{l}\text { Diaphorobacter } \\
\text { sp. LR2014-1 }\end{array}$ & $\begin{array}{l}\text { A disused pesticide } \\
\text { factory, China }\end{array}$ & Zhang et al., 2018 \\
\hline LahB & $\begin{array}{l}\text { Metal-dependent hydrolase } \\
\text { subfamily, amidohydrolase } \\
\text { superfamily }\end{array}$ & QDQ16834.1 & Linuron & $\begin{array}{c}\mathrm{pH} 7.0, \text { Temp } 30^{\circ} \mathrm{C}, \mathrm{K}_{\mathrm{m}} \\
37.3 \pm 1.2 \mu \mathrm{M} \text { (for linuron), MW } \\
49.8 \mathrm{KDa}\end{array}$ & $\begin{array}{l}\text { Sphingobium } \\
\text { sp. SMB }\end{array}$ & $\begin{array}{l}\text { Herbicide- } \\
\text { contaminated soil, } \\
\text { China }\end{array}$ & Zhang et al., 2020 \\
\hline
\end{tabular}

DM refers to N, N-dimethyl-substituted phenylurea herbicides; OM refers to N-methoxy-N-methyl-substituted phenylurea herbicides; $M W$ refers to molecular weight.

that the addition of cytochrome P450 inhibitors significantly reduced the ability of fungi to degrade DUR, suggesting that cytochrome P450 is an enzyme involved in the degradation of

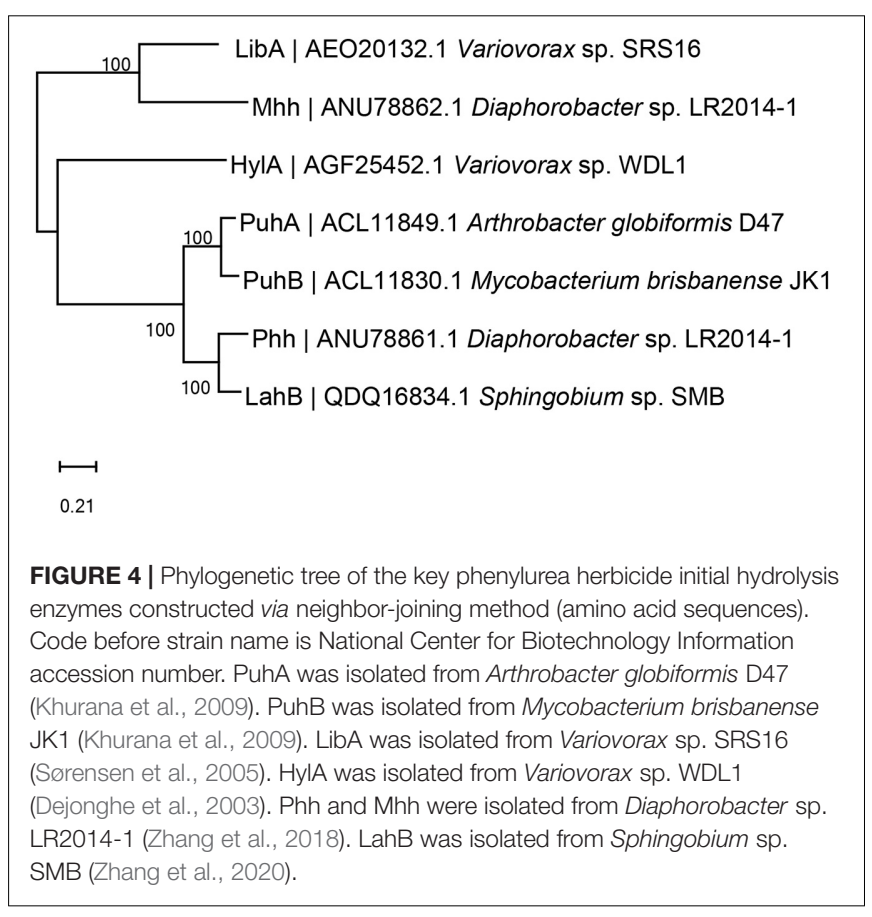

DUR, which is in agreement with a previous study developed by Abass et al. (2007), who considered cytochrome P450 to be an enzyme involved in demethylation of DUR in humans and other mammals. Moreover, exposure to DUR increases the production of lignin peroxidase (Coelho-Moreira et al., 2013; Mori et al., 2018). Coelho-Moreira et al. (2018) showed that the maximal production of laccase occurred simultaneously with maximal DUR degradation. They also confirmed that crude laccase extracts from the white-rot fungus Ganoderma lucidum could degrade. In contrast to Coelho-Moreira et al. (2018) and Henn et al. (2020) applied crude enzymatic extracts of Pycnoporus sanguineus but did not catalyze the degradation of DUR in vitro, despite the high degradation rate of $P$. sanguineus and the strong inductive effect of DUR on laccase synthesis and secretion. Hu et al. (2020) observed that DUR concentrations remained constant after incubating T. versicolor laccase in in vitro experiments, despite substantial laccase activity. Further studies are needed to elucidate the mechanisms of laccase, cytochrome P450, and other enzymes during DUR degradation.

\section{PREVENTIVE BIOREMEDIATION USING DIURON-DEGRADING MICROORGANISMS}

Bioaugmentation is considered an efficient way to remediate DUR-polluted sites by introducing specific degrading 
microorganisms (Cycoń et al., 2017; Arora et al., 2018; Feng et al., 2020; Lin et al., 2020). Although a considerable number of DUR-degrading microorganisms have been isolated, identified, and characterized and their metabolic mechanisms have been elucidated, their ability to remediate DUR-contaminated environmental matrices, such as water, soil, and subsurface material, remains a major challenge (Huang et al., 2017). Previous studies have focused on the degradation ability of bacteria and fungi in aqueous media (Ellegaard-Jensen et al., 2014; Villaverde et al., 2018). Recently, an increasing number of studies have focused on remediation in aquatic environments, slurry, and soil (Chen et al., 2014; Mishra et al., 2021). To prevent active ingredients from leaching into non-target areas, Carles et al. (2021) provided a preventive bioremediation method. Through the simultaneous application of the herbicide 2,4-D and degrading bacteria on planted mesocosms, they reported that 2,4-D was efficient in removing the weeds, and it was rapidly mineralized by the inoculated degraders.

The ability of microorganisms to remove xenobiotics is ultimately dependent on the bioavailability of herbicides and the surrounding conditions, including the soil type, the physicochemical properties of the soil, $\mathrm{pH}$, humidity, temperature, nutrient availability, and oxygen level (Turnbull et al., 2001; Maqbool et al., 2016; Dias Guimaraes et al., 2018). Supplementation of soils with 1 and $2 \%$ biochar enhanced the adsorption, slowed desorption, and reduced the biodegradation of isoproturon (Sopena et al., 2012). Dias Guimaraes et al. (2018) reported that the chemical properties of the soil affect the DUR $\mathrm{DT}_{50}$ value, but no correlation between DUR degradation and organic carbon content and $\mathrm{pH}$ was found. The effect of soil chemical properties on adsorption may outweigh that of degradation. DUR adsorption in the soil is decreased with increasing $\mathrm{pH}$ values, with high adsorption levels at relatively low $\mathrm{pH}$ values (Liu et al., 2010). Higher cation exchange capacity values led to greater DUR colloid sorption, so lower herbicide degradation would be expected. A higher organic carbon content increased the number of degrading microbes but also increased the adsorption of DUR, making it unavailable for microbial degradation. Thus, the conditions must be optimized in the pollutants selected and their physicochemical properties (Grandclement et al., 2017).

Bioreactors are a novel way to treat effluents containing pesticide active ingredients in situ (La Cecilia and Maggi, 2017; Góngora-Echeverría et al., 2020). Recently, novel biobed bioremediation systems have been used to enhance the bioavailability of herbicides and create optimal conditions for herbicide biodegradation, achieving a decontamination efficiency of $75 \%$ for DUR (Delgado-Moreno et al., 2017). The oxygen level, nitrogen level, recycling ratios, and influent flow rates are generally considered to be strongly related to the efficiency of herbicide removal (Hu et al., 2020). According to Castañón-González et al. (2016), there is a higher degradation rate and less 3,4-DCA accumulation in an aerobic reactor than in an oxygen-limited reactor. However, Stasinakis et al. (2009) found that almost $60 \%$ of DUR was biodegraded when using 3,4-DCA as a major metabolite under aerobic conditions, whereas there was more than 95\% degradation with DCPU as a major metabolite under anoxic conditions. Further studies are required to evaluate the removal efficiency in oxygen levels.

Survival, proliferation, immobilization, competition with indigenous bacteria, and catalytic capacity are important factors influencing the biodegradation ability of inoculants (Chen et al., 2013; Zhang et al., 2018, 2021; Bhatt et al., 2019). In addition to environmental factors, the characteristics of the microbes themselves also have an important effect on their degradation ability (Chan et al., 2021). Embedding functional enzymes and microbes with biomaterials or nanomaterials has been of increasing interest to facilitate in situ bioremediation. Organophosphorus hydrolase has been assembled in outer membrane vesicles to enhance the degradation of organophosphate pesticides, hydrolase recovery, and reuse capability ( $\mathrm{Su}$ et al., 2017). Natural cellulose and herbivore waste are also suitable materials owing to their excellent biocompatibility. Liu et al. (2018) immobilized the strain A. globiformis D47 on the fiber networks of nanocellulose and showed that the application of bacteria-decorated nanocellulose produced a higher degradation rate of DUR under different conditions. Silkworm excrement has also been used to immobilize the same bacterium, showing a high survival rate and stable catalytic degradation of DUR (Liu et al., 2019).

\section{CONCLUSION AND FUTURE PERSPECTIVES}

More recent attention has focused on the removal of DUR from contaminated sites. Bioremediation is one of the most effective and eco-friendly ways to degrade DUR. However, due to the poor culturability of microorganisms, only a few bacterial strains capable of mineralizing have been reported. Most strains can hydrolyze DUR to 3,4-DCA but fail to completely mineralize DUR. The molecule 3,4-DCA is a common product of the intermediate metabolism of DUR and linuron degradation; a combination of these degraders for co-metabolism degradation of coexisting herbicides could provide valuable insights for future research. DUR degraders do not seem to be limited to any specific genus or species, unlike in the PUH linuron, which has been reported to have the genus Variovorax as its predominant bacterial strain. Therefore, axenic culture or constructed consortia are needed to achieve the complete mineralization of DUR. The relationship and interaction of individuals in consortia should also be tested to optimize their performance.

A number of studies have evaluated the efficiency of biodegradation under in vitro conditions in liquid cultures. Laboratory studies on the degradation in soil or large-scale field studies in situ are also needed to integrate all the factors that could influence degradation and evaluate the chemistry, toxicity, and environmental fates of DUR and its 
metabolites. In situ removal of target pollutants, colonization, and immobilization are important for microorganisms to survive and degrade specific molecules. Compared with the direct utilization of degraders, embedding functional microbes in biomaterials or emerging nanomaterials will enhance their bioavailability and create optimal conditions to facilitate bioremediation in complex environments.

\section{AUTHOR CONTRIBUTIONS}

SC conceived of the presented idea. JL contributed to the writing and prepared the figures and tables. WZ, ZL, YH, PB, and SC

\section{REFERENCES}

Abass, K., Reponen, P., Turpeinen, M., Jalonen, J., and Pelkonen, O. (2007). Characterization of diuron $N$-demethylation by mammalian hepatic microsomes and cDNA-expressed human cytochrome P450 enzymes. Drug Metab. Dispos. 35, 1634-1641. doi: 10.1124/dmd.107.016295

Akcha, F., Barranger, A., and Bachère, E. (2020). Genotoxic and epigenetic effects of diuron in the Pacific oyster: in vitro evidence of interaction between DNA damage and DNA methylation. Environ. Sci. Pollut. Res. 28, 8266-8280. doi: 10.1007/s11356-020-11021-6

Albers, P., Weytjens, B., De Mot, R., Marchal, K., and Springael, D. (2018). Molecular processes underlying synergistic linuron mineralization in a triplespecies bacterial consortium biofilm revealed by differential transcriptomics. MicrobiologyOpen 7:e559. doi: 10.1002/mbo3.559

Arora, P. K., Srivastava, A., Garg, S. K., and Singh, V. P. (2018). Recent advances in degradation of chloronitrophenols. Bioresour. Technol. 250, 902-909. doi: 10.1016/j.biortech.2017.12.007

Attaway, H. H., Camper, N. D., and Paynter, M. J. B. (1982). Anaerobic microbial degradation of diuron by pond sediment. Pestic. Biochem. Physiol. 17, 96-101. doi: 10.1016/0048-3575(82)90130-4

Behrens, D., Rouxel, J., Burgeot, T., and Akcha, F. (2016). Comparative embryotoxicity and genotoxicity of the herbicide diuron and its metabolites in early life stages of Crassostrea gigas: implication of reactive oxygen species production. Aquat. Toxicol. 175, 249-259. doi: 10.1016/j.aquatox.2016.0 4.003

Bers, K., Batisson, I., Proost, P., Wattiez, R., De Mot, R., and Springael, D. (2013). HylA, an alternative hydrolase for initiation of catabolism of the phenylurea herbicide linuron in Variovorax sp. strains. Appl. Environ. Microbiol. 79, 52585263. doi: 10.1128/AEM.01478-13

Bers, K., Leroy, B., Breugelmans, P., Albers, P., Lavigne, R., Sørensen, S. R., et al. (2011). A novel hydrolase identified by genomic-proteomic analysis of phenylurea herbicide mineralization by Variovorax sp. strain SRS16. Appl. Environ. Microbiol. 77, 8754-8764. doi: 10.1128/AEM.06162-11

Bers, K., Sniegowski, K., De Mot, R., and Springael, D. (2012). Dynamics of the linuron hydrolase $l i b A$ gene pool size in response to linuron application and environmental perturbations in agricultural soil and on-farm biopurification systems. Appl. Environ. Microbiol. 78, 2783-2789. doi: 10.1128/AEM.069 91-11

Bhatt, P., Bhandari, G., Bhatt, K., Maithani, D., Mishra, S., Gangola, S., et al. (2021e). Plasmid-mediated catabolism for the removal of xenobiotics from the environment. J. Hazard. Mater. 420:126618. doi: 10.1016/j.jhazmat.2021. 126618

Bhatt, P., Bhatt, K., Sharma, A., Zhang, W., Mishra, S., and Chen, S. (2021a). Biotechnological basis of microbial consortia for the removal of pesticides from the environment. Crit. Rev. Biotechnol. 41:32. doi: 10.1080/07388551.2020. 1853032

Bhatt, P., Gangola, S., Bhandari, G., Zhang, W., Maithani, D., Mishra, S., et al. (2021b). New insights into the degradation of synthetic pollutants in contaminated environments. Chemosphere 258:128827. doi: 10.1016/j. chemosphere.2020.128827 participated in revising the manuscript. All the authors approved it for publication.

\section{FUNDING}

This study was supported by grants from the KeyArea Research and Development Program of Guangdong Province, China (2018B020206001 and 2020B0202090001), the Natural Science Foundation of Guangdong Province, China (2021A1515010889), and the Guangdong Special Branch Plan for Young Talent with Scientific and Technological Innovation, China (2017TQ04N026).

Bhatt, P., Huang, Y., Zhan, H., and Chen, S. (2019). Insight into microbial applications for the biodegradation of pyrethroid insecticides. Front. Microbiol. 10:1778. doi: 10.3389/fmicb.2019.01778

Bhatt, P., Joshi, T., Bhatt, K., Zhang, W., Huang, Y., and Chen, S. (2021d). Binding interaction of glyphosate with glyphosate oxidoreductase and C-P lyase: molecular docking and molecular dynamics simulation studies. J. Hazard. Mater. 409:124927. doi: 10.1016/j.jhazmat.2020.124927

Bhatt, P., Rene, E. R., Zhang, W., and Chen, S. (2020). Binding interaction of allethrin with esterase: bioremediation potential and mechanism. Bioresour. Technol. 315:123845. doi: 10.1016/j.biortech.2020.123845

Bhatt, P., Zhou, X., Huang, Y., Zhang, W., and Chen, S. (2021c). Characterization of the role of esterases in the biodegradation of organophosphate, carbamate, and pyrethroid pesticides. J. Hazard. Mater. 411:125026. doi: 10.1016/j.jhazmat. 2020.125026

Birolli, W. G., Lima, R. N., and Porto, A. L. M. (2019). Applications of marine-derived microorganisms and their enzymes in biocatalysis and biotransformation, the underexplored potentials. Front. Microbiol. 10:1453. doi: 10.3389/fmicb.2019.01453

Boscolo, C. N. P., Pereira, T. S. B., Batalhão, I. G., Dourado, P. L. R., Schlenk, D., and de Almeida, E. A. (2018). Diuron metabolites act as endocrine disruptors and alter aggressive behavior in Nile tilapia (Oreochromis niloticus). Chemosphere 191, 832-838. doi: 10.1016/j.chemosphere.2017.1 0.009

Brodie, J., and Landos, M. (2019). Pesticides in Queensland and Great Barrier Reef waterways - potential impacts on aquatic ecosystems and the failure of national management. Estuar. Coast. Shelf Sci. 230:106447. doi: 10.1016/j.ecss. 2019.106447

Camenzuli, L., Scheringer, M., Gaus, C., Ng, C. A., and Hungerbühler, K. (2012). Describing the environmental fate of diuron in a tropical river catchment. Sci. Total Environ. 440, 178-185. doi: 10.1016/j.scitotenv.2012. 07.037

Carazo-Rojas, E., Pérez-Rojas, G., Pérez-Villanueva, M., Chinchilla-Soto, C., ChinPampillo, J. S., Aguilar-Mora, P., et al. (2018). Pesticide monitoring and ecotoxicological risk assessment in surface water bodies and sediments of a tropical agro-ecosystem. Environ. Pollut. 241, 800-809. doi: 10.1016/j.envpol. 2018.06.020

Carles, L., Martin-Laurent, F., Devers, M., Spor, A., Rouard, N., Beguet, J., et al. (2021). Potential of preventive bioremediation to reduce environmental contamination by pesticides in an agricultural context: a case study with the herbicide 2,4-D. J. Hazard. Mater. 416:125740. doi: 10.1016/j.jhazmat.2021. 125740

Castañón-González, J. H., Galíndez-Mayer, J., Ruiz-Ordaz, N., Rocha-Martínez, L., Peña-Partida, J. C., Marrón-Montiel, E., et al. (2016). Biodegradation of the herbicide Diuron in a packed bed channel and a double biobarrier with distribution of oxygenated liquid by airlift devices: influence of oxygen limitation. N. Biotechnol. 33, 7-15. doi: 10.1016/j.nbt.2015.07.002

Castillo, M. A., Felis, N., Aragon, P., Cuesta, G., and Sabater, C. (2006). Biodegradation of the herbicide diuron by streptomycetes isolated from soil. Int. Biodeterior. Biodegrad. 58, 196-202. doi: 10.1016/j.ibiod.2006. 06.020 
Chan, H. S., Xiao, K., Tsang, T. H., Zeng, C., Wang, B., Peng, X., et al. (2021). Bioremediation of crude glycerol by a sustainable organicmicrobe hybrid system. Front. Microbiol. 12:654033. doi: 10.3389/fmicb.2021.6 54033

Chen, S., Chang, C., Deng, Y., An, S., Dong, Y. H., Zhou, J., et al. (2014). Fenpropathrin biodegradation pathway in Bacillus sp. DG-02 and its potential for bioremediation of pyrethroid-contaminated soils. J. Agric. Food Chem. 62, 2147-2157. doi: 10.1021/jf404908j

Chen, S., Dong, Y. H., Chang, C., Deng, Y., Zhang, X. F., Zhong, G., et al. (2013). Characterization of a novel cyfluthrin-degrading bacterial strain Brevibacteriu maureum and its biochemical degradation pathway. Bioresour. Technol. 132, 16-23. doi: 10.1016/j.biortech.2013.01.002

Coelho-Moreira, J., da, S., Bracht, A., de Souza, A. C., da, S., Oliveira, R. F., et al. (2013). Degradation of diuron by Phanerochaete chrysosporium: role of ligninolytic enzymes and cytochrome P450. Biomed. Res. Int. 2013:251354. doi: $10.1155 / 2013 / 251354$

Coelho-Moreira, J., da, S., Brugnari, T., Sá-Nakanishi, A. B., Castoldi, R., de Souza, C. G. M., et al. (2018). Evaluation of diuron tolerance and biotransformation by the white-rot fungus Ganoderma lucidum. Fungal Biol. 122, 471-478. doi: 10.1016/j.funbio.2017.10.008

Cui, Y. T., Teo, S. L. M., Leong, W., and Chai, C. L. L. (2014). Searching for "Environmentally-Benign" antifouling biocides. Int. J. Mol. Sci. 15, 9255-9284. doi: 10.3390/ijms 15069255

Cullington, J. E., and Walker, A. (1999). Rapid biodegradation of diuron and other phenylurea herbicides by a soil bacterium. Soil Biol. Biochem. 31, 677-686. doi: 10.1016/S0038-0717(98)00156-4

Cycoń, M., Mrozik, A., and Piotrowska-Seget, Z. (2017). Bioaugmentation as a strategy for the remediation of pesticide-polluted soil: a review. Chemosphere 172, 52-71. doi: 10.1016/j.chemosphere.2016.12.129

da Rocha, M. S., Arnold, L. L., Dodmane, P. R., Pennington, K. L., Qiu, F., De Camargo, J. L. V., et al. (2013). Diuron metabolites and urothelial cytotoxicity: in vivo, in vitro and molecular approaches. Toxicology 314, 238-246. doi: 10. 1016/j.tox.2013.10.005

da Silva Teófilo, T. M., Mendes, K. F., Fernandes, B. C. C., de Oliveira, F. S., Silva, T. S., Takeshita, V., et al. (2020). Phytoextraction of diuron, hexazinone, and sulfometuron-methyl from the soil by green manure species. Chemosphere 256:127059. doi: 10.1016/j.chemosphere.2020.127059

Dages, C., Samouelian, A., Negro, S., Storck, V., Huttel, O., and Voltz, M. (2015). Seepage patterns of diuron in a ditch bed during a sequence of flood events. Sci. Total Environ. 537, 120-128. doi: 10.1016/j.scitotenv.2015. 07.130

de Souza, F. M., and Dos Santos, O. A. A. (2020). Adsorption of diuron from aqueous solution onto commercial organophilic clay: kinetic, equilibrium and thermodynamic study. Environ. Technol. 41, 603-616. doi: 10.1080/09593330. 2018.1505967

Dejonghe, W., Berteloot, E., Goris, J., Boon, N., Crul, K., Maertens, S., et al. (2003). Synergistic degradation of linuron by a bacterial consortium and isolation of a single linuron-degrading variovorax strain. Appl. Environ. Microbiol. 69, 1532-1541. doi: 10.1128/aem.69.3.1532-1541.2003

Delgado-Moreno, L., Nogales, R., and Romero, E. (2017). Biodegradation of high doses of commercial pesticide products in pilot-scale biobeds using olive-oil agroindustry wastes. J. Environ. Manage. 204, 160-169. doi: 10.1016/j.jenvman. 2017.08.032

Devers-Lamrani, M., Pesce, S., Rouard, N., and Martin-Laurent, F. (2014). Evidence for cooperative mineralization of diuron by Arthrobacter sp. BS2 and Achromobacter sp. SP1 isolated from a mixed culture enriched from diuron exposed environments. Chemosphere 117, 208-215. doi: 10.1016/j. chemosphere.2014.06.080

Dias Guimaraes, A. C., Mendes, K. F., dos Reis, F. C., Campion, T. F., Christoffoleti, P. J., and Tornisielo, V. L. (2018). Role of soil physicochemical properties in quantifying the fate of diuron, hexazinone, and metribuzin. Environ. Sci. Pollut. Res. 25, 12419-12433. doi: 10.1007/s11356-018-1 469-5

Diepens, N. J., Buffan-Dubau, E., Budzinski, H., Kallerhoff, J., Merlina, G., Silvestre, J., et al. (2017). Toxicity effects of an environmental realistic herbicide mixture on the seagrass Zostera noltei. Environ. Pollut. 222, 393-403. doi: 10.1016/j. envpol.2016.12.021
Dores, E. F. G. C., Spadotto, C. A., Weber, O. L. S., Carbo, L., Vecchiato, A. B., and Pinto, A. A. (2009). Environmental behaviour of metolachlor and diuron in a tropical soil in the central region of Brazil. Water Air Soil Pollut. 197, 175-183. doi: 10.1007/s11270-008-9801-1

Dos Reis, F. C., Tornisielo, V. L., Pimpinato, R. F., Martins, B. A. B. and Victória Filho, R. (2017). Leaching of diuron, hexazinone, and sulfometuron-methyl applied alone and in mixture in soils with contrasting textures. J. Agric. Food Chem. 65, 2645-2650. doi: 10.1021/acs.jafc. $6 \mathrm{~b} 05127$

Dunon, V., Sniegowski, K., Bers, K., Lavigne, R., Smalla, K., and Springael, D. (2013). High prevalence of IncP-1 plasmids and IS1071 insertion sequences in on-farm biopurification systems and other pesticide-polluted environments. FEMS Microbiol. Ecol. 86, 415-431. doi: 10.1111/1574-6941. 12173

Dupraz, V., Coquillé, N., Ménard, D., Sussarellu, R., Haugarreau, L., and Stachowski-Haberkorn, S. (2016). Microalgal sensitivity varies between a diuron-resistant strain and two wild strains when exposed to diuron and irgarol, alone and in mixtures. Chemosphere 151, 241-252. doi: 10.1016/j.chemosphere. 2016.02.073

DWI (2013). Data Summary Tables for Essex and Suffolk Water (ESK). London: DWI (Drinking Water Inspectorate).

Egea, T. C., da Silva, R., Boscolo, M., Rigonato, J., Monteiro, D. A., Grünig, D., et al. (2017). Diuron degradation by bacteria from soil of sugarcane crops. Heliyon 3:e00471. doi: 10.1016/j.heliyon.2017.e00471

Egea, T., Rodrigues, A., Morais, P., Da Silva, R., and Gomes, E. (2014). Assessment of fungi in soils of sugarcane crops and their potential for production of biomass-degrading enzymes. Afr. J. Microbiol. Res. 8, 3751-3760. doi: 10.5897/ AJMR2014.7016

Eletto, D., Reppucci, F., Ronga, A., Altieri, V., Brongo, S., Martinelli, R., et al. (2020). Modulation of BAG3 expression in human normal urothelial cells by Diuron. J. Cell Physiol. 236, 2616-2619. doi: 10.1002/jcp. 30016

Ellegaard-Jensen, L., Aamand, J., Kragelund, B. B., Johnsen, A. H., and Rosendahl, S. (2013). Strains of the soil fungus Mortierella show different degradation potentials for the phenylurea herbicide diuron. Biodegradation 24, 765-774. doi: $10.1007 /$ s10532-013-9624-7

Ellegaard-Jensen, L., Knudsen, B. E., Johansen, A., Albers, C. N., Aamand, J., and Rosendahl, S. (2014). Fungal-bacterial consortia increase diuron degradation in water-unsaturated systems. Sci. Total Environ. 466-467, 699-705. doi: 10.1016/ j.scitotenv.2013.07.095

Engelhardt, G., Wallnöfer, P. R., and Plapp, R. (1971). Degradation of linuron and some other herbicides and fungicides by a linuron-inducible enzyme obtained from Bacillus sphaericus. Appl. Microbiol. 22, 284-288. doi: 10.1128/aem.22.3. 284-288.1971

Engelhardt, G., Wallnöfer, P. R., and Plapp, R. (1973). Purification and properties of an aryl acylamidase of Bacillus sphaericus, catalyzing the hydrolysis of various phenylamide herbicides and fungicides. Appl. Microbiol. 26, 709-718. doi: 10.1128/am.26.5.709-718.1973

EFSA (2005). Conclusion regarding the peer review of the pesticide risk assessment of the active substance Diuron. EFSA J. 3:25r. doi: 10.2903/j.efsa.20 $05.25 \mathrm{r}$

Felício, A. A., Freitas, J. S., Scarin, J. B., de Souza Ondei, L., Teresa, F. B., Schlenk, D., et al. (2018). Isolated and mixed effects of diuron and its metabolites on biotransformation enzymes and oxidative stress response of Nile tilapia (Oreochromis niloticus). Ecotoxicol. Environ. Saf. 149, 248-256. doi: 10.1016/j. ecoenv.2017.12.009

Feng, Y., Huang, Y., Zhan, H., Bhatt, H., and Chen, S. (2020). An overview of strobilurin fungicide degradation: current status and future perspective. Front. Microbiol. 10:389. doi: 10.3389/fmicb.2020.00389

Fernandes, G. S. A., Arena, A. C., Fernandez, C. D. B., Mercadante, A., Barbisan, L. F., and Kempinas, W. G. (2007). Reproductive effects in male rats exposed to diuron. Reprod. Toxicol. 23, 106-112. doi: 10.1016/j.reprotox.2006. 09.002

Field, J. A., Reed, R. L., Sawyer, T. E., Griffith, S. M., and Wigington, P. J. Jr. (2003). Diuron occurrence and distribution in soil and surface and ground water associated with grass seed production. J. Environ. Qual. 32, 171-179. doi: $10.2134 /$ jeq2003.171 
Giacomazzi, S., and Cochet, N. (2004). Environmental impact of diuron transformation: a review. Chemosphere 56, 1021-1032. doi: 10.1016/j. chemosphere.2004.04.061

Góngora-Echeverría, V. R., García-Escalante, R., Rojas-Herrera, R., GiácomanVallejos, G., and Ponce-Caballero, C. (2020). Pesticide bioremediation in liquid media using a microbial consortium and bacteria-pure strains isolated from a biomixture used in agricultural areas. Ecotoxicol. Environ. Saf. 200:110734. doi: 10.1016/j.ecoenv.2020.110734

Grandclement, C., Seyssiecq, I., Piram, A., Wong-Wah-Chung, P., Vanot, G., Tiliacos, N., et al. (2017). From the conventional biological wastewater treatment to hybrid processes, the evaluation of organic micropollutant removal: a review. Water Res. 111, 297-317. doi: 10.1016/j.watres.2017.0 1.005

Grgić, D. K., Bulatović, V. O., Cvetnić, M., Vučinić, ŽD., Domanovac, M. V., Markić, M., et al. (2020). Biodegradation kinetics of diuron by Pseudomonas aeruginosa $\mathrm{FN}$ and optimization of biodegradation using response surface methodology. Water Environ. J. 34, 61-73. doi: 10.1111/wej. 12505

Henn, C., Arakaki, R. M., Monteiro, D. A., Boscolo, M., da Silva, R., and Gomes, E. (2020). Degradation of the organochlorinated herbicide diuron by rainforest basidiomycetes. Biomed. Res. Int. 2020:5324391. doi: 10.1155/2020/53 24391

Hongsawat, P., and Vangnai, A. S. (2011). Biodegradation pathways of chloroanilines by Acinetobacter baylyi strain GFJ2. J. Hazard. Mater. 186, 1300-1307. doi: 10.1016/j.jhazmat.2010.12.002

Hu, K., Torán, J., López-García, E., Barbieri, M. V., Postigo, C., de Alda, M. L., et al. (2020). Fungal bioremediation of diuron-contaminated waters: evaluation of its degradation and the effect of amendable factors on its removal in a trickle-bed reactor under non-sterile conditions. Sci. Total Environ. 743:140628. doi: 10.1016/j.scitotenv.2020.140628

Huang, X., He, J., Yan, X., Hong, Q., Chen, K., He, Q., et al. (2017). Microbial catabolism of chemical herbicides: microbial resources, metabolic pathways and catabolic genes. Pestic. Biochem. Physiol. 143, 272-297. doi: 10.1016/j.pestbp. 2016.11.010

Huang, Y., Lin, Z., Zhang, W., Pang, S., Bhatt, P., Rene, E. R., et al. (2020). New insights into the microbial degradation of $D$-cyphenothrin in contaminated water/soil environments. Microorganisms 8:473. doi: 10.3390/ microorganisms8040473

Huang, Y., Zhang, W., Pang, S., Chen, J., Bhatt, P., Mishra, S., et al. (2021). Insights into the microbial degradation and catalytic mechanisms of chlorpyrifos. Environ. Res. 194:110660. doi: 10.1016/j.envres.2020. 110660

Huovinen, M., Loikkanen, J., Naarala, J., and Vähäkangas, K. (2015). Toxicity of diuron in human cancer cells. Toxicol. In Vitro 29, 1577-1586. doi: 10.1016/j. tiv.2015.06.013

Hussain, S., Arshad, M., Springael, D., Sorensen, S. R., Bending, G. D., DeversLamrani, M., et al. (2015). Abiotic and biotic processes governing the fate of phenylurea herbicides in soils: a review. Crit. Rev. Environ. Sci. Technol. 45, 1947-1998. doi: 10.1080/10643389.2014.1001141

Ihlaseh-Catalano, S. M., Bailey, K. A., Cardoso, A. P. F., Ren, H., Fry, R. C., de Camargo, J. L. V., et al. (2014). Dose and temporal effects on gene expression profiles of urothelial cells from rats exposed to diuron. Toxicology 325, 21-30. doi: 10.1016/j.tox.2014.08.005

Khurana, J. L., Jackson, C. J., Scott, C., Pandey, G., Horne, I., Russell, R. J., et al. (2009). Characterization of the phenylurea hydrolases A and B: founding members of a novel amidohydrolase subgroup. Biochem. J. 418, 431-441. doi: 10.1042/BJ20081488

King, J., Alexander, F., and Brodie, J. (2013). Regulation of pesticides in Australia: the Great Barrier Reef as a case study for evaluating effectiveness. Agric. Ecosyst. Environ. 180, 54-67. doi: 10.1016/j.agee.2012. 07.001

La Cecilia, D., and Maggi, F. (2017). In-situ atrazine biodegradation dynamics in wheat (Triticum) crops under variable hydrologic regime. J. Contam. Hydrol. 203, 104-121. doi: 10.1016/j.jconhyd.2017.05.004

Landry, D., Dousset, S., and Andreux, F. (2006). Leaching of oryzalin and diuron through undisturbed vineyard soil columns under outdoor conditions. Chemosphere 62, 1736-1747. doi: 10.1016/j.chemosphere.2005.0 6.024
Lin, Z., Pang, S., Zhang, W., Mishra, S., Bhatt, P., and Chen, S. (2020). Degradation of acephate and its intermediate methamidophos: mechanisms and biochemical pathways. Front. Microbiol. 11:2045. doi: 10.3389/fmicb.2020. 02045

Liu, B., Wang, H., Zhang, K., Zhu, J., He, Q., and He, J. (2020). Improved herbicide resistance of 4-hydroxyphenylpyruvate dioxygenase from Sphingobium sp. TPM-19 through directed evolution. J. Agric. Food Chem. 68, 12365-12374. doi: 10.1021/acs.jafc.0c05785

Liu, J., Morales-Narváez, E., Vicent, T., Merkoçi, A., and Zhong, G. H. (2018). Microorganism-decorated nanocellulose for efficient diuron removal. Chem. Eng. J. 354, 1083-1091. doi: 10.1016/j.cej.2018.08.035

Liu, J., Yang, M., Wang, Y., Qu, L., and Zhong, G. (2019). Enhanced diuron remediation by microorganism-immobilized silkworm excrement composites and their impact on soil microbial communities. J. Hazard. Mater. 376, 29-36. doi: 10.1016/j.jhazmat.2019.05.014

Liu, Y., Xu, Z., Wu, X., Gui, W., and Zhu, G. (2010). Adsorption and desorption behavior of herbicide diuron on various Chinese cultivated soils. J. Hazard. Mater. 178, 462-468. doi: 10.1016/j.jhazmat.2010.01.105

Loos, R., Gawlik, B. M., Locoro, G., Rimaviciute, E., Contini, S., and Bidoglio, G. (2009). EU-wide survey of polar organic persistent pollutants in European river waters. Environ. Pollut. 157, 561-568. doi: 10.1016/j.envpol.2008. 09.020

Lu, H., Yu, Q., Han, H., Owen, M. J., and Powles, S. B. (2019). A novel psbA mutation (Phe274-Val) confers resistance to PSII herbicides in wild radish (Raphanus raphanistrum). Pest Manag. Sci. 75, 144-151. doi: 10.1002/p s.5079

Manonmani, G., Sandhiya, L., and Senthilkumar, K. (2020). Mechanism and kinetics of diuron oxidation by hydroxyl radical addition reaction. Environ. Sci. Pollut. Res. 27, 12080-12095. doi: 10.1007/s11356-020-07806-4

Maqbool, Z., Hussain, S., Imran, M., Mahmood, F., Shahzad, T., Ahmed, Z., et al. (2016). Perspectives of using fungi as bioresource for bioremediation of pesticides in the environment: a critical review. Environ. Sci. Pollut. Res. 23, 16904-16925. doi: 10.1007/s11356-016-7003-8

Marques, J. A., Flores, F., Patel, F., Bianchini, A., Uthicke, S., and Negri, A. P. (2020). Acclimation history modulates effect size of calcareous algae (Halimeda opuntia) to herbicide exposure under future climate scenarios. Sci. Total Environ. 739:140308. doi: 10.1016/j.scitotenv.2020.140308

Mendez, A., Castillo, L. E., Ruepert, C., Hungerbuehler, K., and Ng, C. A. (2018). Tracking pesticide fate in conventional banana cultivation in Costa Rica: a disconnect between protecting ecosystems and consumer health. Sci. Total Environ. 613, 1250-1262. doi: 10.1016/j.scitotenv.2017.09.172

Mercurio, P., Eaglesham, G., Parks, S., Kenway, M., Beltran, V., Flores, F., et al. (2018). Contribution of transformation products towards the total herbicide toxicity to tropical marine organisms. Sci. Rep. 8:4808. doi: 10.1038/s41598018-23153-4

Mercurio, P., Mueller, J. F., Eaglesham, G., O’Brien, J., Flores, F., and Negri, A. P. (2016). Degradation of herbicides in the tropical marine environment: influence of light and sediment. PLoS One 11:e0165890. doi: 10.1371/journal. pone. 0165890

Mishra, S., Lin, Z., Pang, S., Zhang, W., Bhatt, P., and Chen, S. (2021). Recent advanced technologies for the characterization of xenobiotic-degrading microorganisms and microbial communities. Front. Bioeng. Biotech. 9:632059. doi: 10.3389/fbioe.2021.632059

Mishra, S., Zhang, W., Lin, Z., Pang, S., Huang, Y., Bhatt, P., et al. (2020). Carbofuran toxicity and its microbial degradation in contaminated environments. Chemosphere 259:127429. doi: 10.1016/j.chemosphere.2020. 127419

Mohammed, A. M., Huovinen, M., and Vähäkangas, K. H. (2020). Toxicity of diuron metabolites in human cells. Environ. Toxicol. Chem. 78:103409. doi: 10.1016/j.etap. 2020.103409

Mohammed, A. M., Karttunen, V., Huuskonen, P., Huovinen, M., Auriola, S., and Vähäkangas, K. (2018). Transplacental transfer and metabolism of diuron in human placenta. Toxicol. Lett. 295, 307-313. doi: 10.1016/j.toxlet.2018.0 7.012

Moisset, S., Kim Tiam, S., Feurtet-Mazel, A., Morin, S., Delmas, F., Mazzella, N., et al. (2015). Genetic and physiological responses of three freshwater diatoms to realistic diuron exposures. Environ. Sci. Pollut. Res. 22, 4046-4055. doi: 10.1007/s11356-014-3523-2 
Moreno-González, R., and León, V. M. (2017). Presence and distribution of current-use pesticides in surface marine sediments from a Mediterranean coastal lagoon (SE Spain). Environ. Sci. Pollut. Res. 24, 8033-8048. doi: 10.1007/ s11356-017-8456-0

Mori, T., Sudo, S., Kawagishi, H., and Hirai, H. (2018). Biodegradation of diuron in artificially contaminated water and seawater by wood colonized with the whiterot fungus Trametes versicolor. J. Wood Sci. 64, 690-696. doi: 10.1007/s10086018-1740-x

Muendo, B. M., Shikuku, V. O., Lalah, J. O., Getenga, Z. M., Wandiga, S. O., and Rothballer, M. (2021). Enhanced degradation of diuron by two Bacillus species isolated from diuron contaminated sugarcane and pineapple-cultivated soils in Kenya. Appl. Soil Ecol. 157:103721. doi: 10.1016/j.apsoil.2020.103721

Negri, A. P., Flores, F., Mercurio, P., Mueller, J. F., and Collier, C. J. (2015). Lethal and sub-lethal chronic effects of the herbicide diuron on seagrass. Aquat. Toxicol. 165, 73-83. doi: 10.1016/j.aquatox.2015.05.007

Ngigi, A., Getenga, Z., Boga, H., and Ndalut, P. (2011). Biodegradation of phenylurea herbicide diuron by microorganisms from long-term-treated sugarcane-cultivated soils in Kenya. Toxicol. Environ. Chem. 93, 1623-1635. doi: 10.1080/02772248.2011.595718

Ozturk, B., Werner, J., Meier-Kolthoff, J. P., Bunk, B., Sproer, C., and Springael, D. (2020). Comparative genomics suggests mechanisms of gene is adaptation toward the catabolism of the phenylurea herbicide linuron in Variovorax. Genome Biol. Evol. 12, 827-841. doi: 10.1093/gbe/evaa085

Pang, S., Lin, Z., Zhang, W., Mishra, S., Bhatt, P., and Chen, S. (2020). Insights into the microbial degradation and biochemical mechanisms of neonicotinoids. Front. Microbiol. 11:868. doi: 10.3389/fmicb.2020.00868

Park, J. M., and Jhung, S. H. (2020). Polyaniline-derived carbons: remarkable adsorbents to remove atrazine and diuron herbicides from water. J. Hazard. Mater. 396:122624. doi: 10.1016/j.jhazmat.2020.122624

Pei, Z. T., Xu, R. R., Liu, H. Y., Wang, W. Q., Zhang, M., Zhang, L. L., et al. (2020). Development and application of a novel whole sediment toxicity test using immobilized sediment and Chlorella vulgaris. Ecotoxicol. Environ. Saf. 189:109979. doi: 10.1016/j.ecoenv.2019.109979

Peng, X., Huang, J., Liu, C., Xiang, Z., Zhou, J., and Zhong, G. (2012). Biodegradation of bensulphuron-methyl by a novel Penicillium pinophilum strain, BP-H-02. J. Hazard. Mater. 213-214, 216-221. doi: 10.1016/j.jhazmat. 2012.01.077

Pereira, T. S. B., Boscolo, C. N. P., Silva, D. G. H., da, Batlouni, S. R., Schlenk, D., et al. (2015). Anti-androgenic activities of diuron and its metabolites in male Nile tilapia (Oreochromis niloticus). Aquat. Toxicol. 164, 10-15. doi: 10.1016/j. aquatox.2015.04.013

Perissini-Lopes, B., Egea, T. C., Monteiro, D. A., Vici, A. C., Da Silva, R., Grunig, D., et al. (2016). Evaluation of Diuron tolerance and biotransformation by fungi from a sugar cane plantation sandy-loam soil. J. Agric. Food Chem. 64, 9268-9275. doi: 10.1021/acs.jafc.6b03247

Pesce, S., Lissalde, S., Lavieille, D., Margoum, C., Mazzella, N., Roubeix, V., et al. (2010). Evaluation of single and joint toxic effects of diuron and its main metabolites on natural phototrophic biofilms using a pollution-induced community tolerance (PICT) approach. Aquat. Toxicol. 99, 492-499. doi: 10. 1016/j.aquatox.2010.06.006

Riascos-Flores, L., Bruneel, S., Van der Heyden, C., Deknock, A., Van Echelpoel, W., Forio, M. A. E., et al. (2020). Polluted paradise: occurrence of pesticide residues within the urban coastal zones of Santa Cruz and Isabela (Galapagos, Ecuador). Sci. Total Environ. 763:142956. doi: 10.1016/j.scitotenv.2020.1 42956

Richards, L. A., Kumari, R., White, D., Parashar, N., Kumar, A., Ghosh, A., et al. (2020). Emerging organic contaminants in groundwater under a rapidly developing city (Patna) in northern India dominated by high concentrations of lifestyle chemicals. Environ. Pollut. 268:115765. doi: 10.1016/j.envpol.2020. 115765

Schrader, K., Rimando, A., Tucker, C., Glinski, J., Cutler, S., and Cutler, H. (2004). Evaluation of the natural product SeaKleen for controlling the Musty-OdorProducing cyanobacterium Oscillatoria perornata in catfish ponds. N. Am. J. Aquacult. 66, 20-28. doi: 10.1577/A03-026

Shareef, A., Page, D., Vanderzalm, J., Williams, M., Gupta, V. V. S. R., Dillon, P., et al. (2014). Biodegradation of simazine and diuron herbicides under aerobic and anoxic conditions relevant to managed aquifer recharge of storm 2ater. Clean Soil Air Water 42, 745-752. doi: 10.1002/clen.201300092
Sharma, P., Chopra, A., Cameotra, S. S., and Suri, C. R. (2010). Efficient biotransformation of herbicide diuron by bacterial strain Micrococcus sp. PS-1. Biodegradation 21, 979-987. doi: 10.1007/s10532-010-9357-9

Sigurnjak, M., Ukić, Š, Cvetnić, M., Markić, M., Novak Stankov, M., Rasulev, B., et al. (2020). Combined toxicities of binary mixtures of alachlor, chlorfenvinphos, diuron and isoproturon. Chemosphere 240:124973. doi: 10. 1016/j.chemosphere.2019.124973

Silambarasan, S., Logeswari, P., Ruiz, A., Cornejo, P., and Kannan, V. R. (2020). Influence of plant beneficial Stenotrophomonas rhizophila strain CASB3 on the degradation of diuron-contaminated saline soil and improvement of Lactuca sativa growth. Environ. Sci. Pollut. Res. 27, 35195-35207. doi: 10.1007/s11356020-09722-z

Singh, A. K., and Singla, P. (2019). Biodegradation of diuron by endophytic Bacillus licheniformis strain SDS12 and its application in reducing diuron toxicity for green algae. Environ. Sci. Pollut. Res. 26, 26972-26981. doi: 10.1007/s11356019-05922-4

Sopena, F., Semple, K., Sohi, S., and Bending, G. (2012). Assessing the chemical and biological accessibility of the herbicide isoproturon in soil amended with biochar. Chemosphere 88, 77-83. doi: 10.1016/j.chemosphere.2012. 02.066

Sorensen, S. R., Albers, C. N., and Aamand, J. (2008). Rapid mineralization of the phenylurea herbicide diuron by Variovorax sp strain SRS16 in pure culture and within a two-member consortium. Appl. Environ. Microbiol. 74, 2332-2340. doi: 10.1128/AEM.02687-07

Sørensen, S. R., Rasmussen, J., Jacobsen, C. S., Jacobsen, O. S., Juhler, R. K., and Aamand, J. (2005). Elucidating the key member of a linuron-mineralizing bacterial community by PCR and reverse transcription-PCR denaturing gradient gel electrophoresis $16 \mathrm{~S}$ rRNA gene fingerprinting and cultivation. Appl. Environ. Microbiol. 71, 4144-4148. doi: 10.1128/AEM.71.7.4144-4148. 2005

Sørensen, S. R., Ronen, Z., and Aamand, J. (2002). Growth in coculture stimulates metabolism of the phenylurea herbicide isoproturon by Sphingomonas sp. strain SRS2. Appl. Environ. Microbiol. 68, 3478-3485. doi: 10.1128/aem.68.7.34783485.2002

Stasinakis, A. S., Kotsifa, S., Gatidou, G., and Mamais, D. (2009). Diuron biodegradation in activated sludge batch reactors under aerobic and anoxic conditions. Water Res. 43, 1471-1479. doi: 10.1016/j.watres.2008.12.040

Stork, P. R., Bennett, F. R., and Bell, M. J. (2008). The environmental fate of diuron under a conventional production regime in a sugarcane farm during the plant cane phase. Pest Manag. Sci. 64, 954-963. doi: 10.1002/ps.1593

Su, F. H., Tabañag, I. D. F., Wu, C. Y., and Tsai, S. L. (2017). Decorating outer membrane vesicles with organophosphorus hydrolase and cellulose binding domain for organophosphate pesticide degradation. Chem. Eng. J. 308, 1-7. doi: 10.1016/j.cej.2016.09.045

Tandon, S., and Pant, R. (2019). Kinetics of diuron under aerobic condition and residue analysis in sugarcane under subtropical field conditions. Environ. Technol. 40, 86-93. doi: 10.1080/09593330.2017.1380709

Thomas, M. C., Flores, F., Kaserzon, S., Fisher, R., and Negri, A. P. (2020). Toxicity of ten herbicides to the tropical marine microalgae Rhodomonas salina. Sci. Rep. 10:7612. doi: 10.1038/s41598-020-64116-y

Tixier, C., Sancelme, M., Aït-Aïssa, S., Widehem, P., Bonnemoy, F., Cuer, A., et al. (2002). Biotransformation of phenylurea herbicides by a soil bacterial strain, Arthrobacter sp. N2: structure, ecotoxicity and fate of diuron metabolite with soil fungi. Chemosphere 46, 519-526. doi: 10.1016/S0045-6535(01)0 0193-X

Turnbull, G. A., Ousley, M., Walker, A., Shaw, E., and Morgan, J. A. (2001). Degradation of substituted phenylurea herbicides by Arthrobacter globiformis strain D47 and characterization of a plasmid-associated hydrolase gene, puhA. Appl. Environ. Microbiol. 67, 2270-2275. doi: 10.1128/AEM.67.5.2270-2275. 2001

Tworkoski, T. J., Welker, W. V., and Vass, G. D. (2000). Soil residues following repeat applications of diuron, simazine, and terbacil. Weed Technol. 14, 191196. doi: 10.1614/0890-037x(2000)014[0191:srfrao]2.0.co;2

van Dam, J. W., Uthicke, S., Beltran, V. H., Mueller, J. F., and Negri, A. P. (2015). Combined thermal and herbicide stress in functionally diverse coral symbionts. Environ. Pollut. 204, 271-279. doi: 10.1016/j.envpol.2015.05.013

Viana, J. L. M., Dos Santos, S. R. V., Dos Santos Franco, T. C. R., and Almeida, M. A. P. (2019). Occurrence and partitioning of antifouling booster 
biocides in sediments and porewaters from Brazilian Northeast. Environ. Pollut. 255:112988. doi: 10.1016/j.envpol.2019.112988

Villaverde, J., Rubio-Bellido, M., Lara-Moreno, A., Merchan, F., and Morillo, E. (2018). Combined use of microbial consortia isolated from different agricultural soils and cyclodextrin as a bioremediation technique for herbicide contaminated soils. Chemosphere 193, 118-125. doi: 10.1016/j.chemosphere. 2017.10.172

Villaverde, J., Rubio-Bellido, M., Merchán, F., and Morillo, E. (2017). Bioremediation of diuron contaminated soils by a novel degrading microbial consortium. J. Environ. Manage. 188, 379-386. doi: 10.1016/j.jenvman.2016. 12.020

Wackett, L. P., Sadowsky, M. J., Martinez, B., and Shapir, N. (2002). Biodegradation of atrazine and related s-triazine compounds: from enzymes to field studies. Appl. Microbiol. Biotechnol. 58, 39-45. doi: 10.1007/s00253-001-0 $862-y$

Wang, Y., Li, H., Feng, G., Du, L., and Zeng, D. (2017). Biodegradation of diuron by an endophytic fungus Neurospora intermedia DP8-1 isolated from sugarcane and its potential for remediating diuron-contaminated soils. PLoS One 12:e0182556. doi: 10.1371/journal.pone.0182556

Wilkinson, A. D., Collier, C. J., Flores, F., Langlois, L., Ralph, P. J., and Negri, A. P. (2017). Combined effects of temperature and the herbicide diuron on photosystem II activity of the tropical seagrass Halophila ovalis. Sci. Rep. 7:45404. doi: 10.1038/srep45404

Zhang, L., Hang, P., Hu, Q., Chen, X. L., Zhou, X. Y., Chen, K., et al. (2018). Degradation of phenylurea herbicides by a novel bacterial consortium containing synergistically catabolic species and functionally complementary hydrolases. J. Agric. Food Chem. 66, 12479-12489. doi: 10.1021/acs.jafc. 8 b03703

Zhang, L., Hu, Q., Liu, B., Li, F., and Jiang, J. D. (2020). Characterization of a linuron-specific amidohydrolase from the newly isolated bacterium Sphingobium sp. strain SMB. J. Agric. Food Chem. 68, 4335-4345. doi: 10.1021/ acs.jafc.0c00597

Zhang, Y., Zhang, W., Li, J., Pang, S., Mishra, S., Bhatt, P., et al. (2021). Emerging technologies for degradation of dichlorvos: a review. Int. J. Environ. Res. Public Health 18:5789. doi: 10.3390/ijerph18115789

Conflict of Interest: The authors declare that the research was conducted in the absence of any commercial or financial relationships that could be construed as a potential conflict of interest.

Publisher's Note: All claims expressed in this article are solely those of the authors and do not necessarily represent those of their affiliated organizations, or those of the publisher, the editors and the reviewers. Any product that may be evaluated in this article, or claim that may be made by its manufacturer, is not guaranteed or endorsed by the publisher.

Copyright (c) 2021 Li, Zhang, Lin, Huang, Bhatt and Chen. This is an open-access article distributed under the terms of the Creative Commons Attribution License (CC BY). The use, distribution or reproduction in other forums is permitted, provided the original author(s) and the copyright owner(s) are credited and that the original publication in this journal is cited, in accordance with accepted academic practice. No use, distribution or reproduction is permitted which does not comply with these terms. 